\title{
Is dental amalgam safe for humans? The opinion of the scientific committee of the European Commission
}

\author{
Joachim Mutter
}

\begin{abstract}
It was claimed by the Scientific Committee on Emerging and Newly Identified Health Risks (SCENIHR)) in a report to the EU-Commission that "...no risks of adverse systemic effects exist and the current use of dental amalgam does not pose a risk of systemic disease..." [1, available from: http://ec.europa.eu/health/ph_risk/committees/ 04_scenihr/docs/scenihr_o_016.pdf].

SCENIHR disregarded the toxicology of mercury and did not include most important scientific studies in their review. But the real scientific data show that:

(a) Dental amalgam is by far the main source of human total mercury body burden. This is proven by autopsy studies which found 2-12 times more mercury in body tissues of individuals with dental amalgam. Autopsy studies are the most valuable and most important studies for examining the amalgam-caused mercury body burden.

(b) These autopsy studies have shown consistently that many individuals with amalgam have toxic levels of mercury in their brains or kidneys.

(c) There is no correlation between mercury levels in blood or urine, and the levels in body tissues or the severity of clinical symptoms. SCENIHR only relied on levels in urine or blood.

(d) The half-life of mercury in the brain can last from several years to decades, thus mercury accumulates over time of amalgam exposure in body tissues to toxic levels. However, SCENIHR state that the half-life of mercury in the body is only "20-90 days".

(e) Mercury vapor is about ten times more toxic than lead on human neurons and with synergistic toxicity to other metals.

( $f$ ) Most studies cited by SCENIHR which conclude that amalgam fillings are safe have severe methodical flaws.
\end{abstract}

\section{Dental amalgam is the main source of mercury in human tissues}

SCENIHR (Scientific Committee on Emerging and Newly Identified Health Risks) from the European Commission claim [1]: "Exposure to mercury is difficult to measure. The indications for mercury exposure are therefore normally obtained by measuring mercury levels in urine and blood of individuals."

SCENIHR did not cite any autopsy studies, which are the most reliable studies for assessing mercury levels in tissues.

An approx. 2-5-fold increase of mercury levels in blood and urine in living individuals with dental

Correspondence: jm@zahnklinik.de

Department of Environmental and integrative medicine Lohnerhofstraße 2, 78467 Constance/Germany amalgam as well as a 2-12 fold increase in several body tissues was observed in deceased individuals with dental amalgam [2-21]. Additionally, studies with animals have confirmed the fact that dental amalgam leads to significantly increased levels in the tissues [22-28].

According to these studies, dental amalgam is responsible for at least $60-95 \%$ of mercury deposits in human tissues. This was not acknowledged by SCENIHR.

\section{No organic mercury compounds through dental amalgam?}

SCENIHR [1] state that "there is no evidence that biotransformation of amalgam derived mercury takes place intra-orally in association with bacterial activity."

\section{() Biomed Central}


In contrast to this claim studies have shown that mercury $(\mathrm{Hg})$ from dental amalgam is transformed into organic mercury compounds by microorganisms in the human gastrointestinal tract [29-31]. Leistevuo et al. (2001) found a three-fold increase of methylmercury levels in saliva of individuals with dental amalgam compared to individuals without amalgam, although frequency and kind of fish consumption were identical in both groups. Mercury levels in saliva exceed mercury limits for sewage in $20 \%$ of individuals with amalgam [30]. The form of methylmercury derived from dental amalgam may be much more toxic (up to 20 times) than the form of methylmercury found in fish (see section "toxicity of mercury").

\section{Toxic mercury levels in vitro and in vivo}

Inorganic mercury levels of $0.02 \mathrm{ng} \mathrm{Hg} / \mathrm{g}(2 \mu \mathrm{l}$ of 0.1 $\mu$ Molar $\mathrm{Hg}$ in $2 \mathrm{ml}$ substrate) led to the total destruction of intracellular mircrotubuli and to the degeneration of axons [32]. In other experiments inorganic mercury levels of $36 \mathrm{ng} \mathrm{Hg} / \mathrm{g}(0.18 \mu \mathrm{Mol} \mathrm{Hg})$ led to increased oxidative stress as a prerequisite for further cell damage [33,34].

Mercury vapor inhalation in doses which also occur in humans with many amalgam fillings and chewing led to pathological changes in the brains of animals after 14 days $[35,36]$.

\section{No toxic mercury levels in humans through dental amalgam?}

In a recent autopsy study, it was found that individuals with more than 12 amalgam fillings have more than 10times higher mercury levels in several tissues including the brain, compared to individuals with only 0-3 amalgam fillings [11].

The average mercury level in the brain of EU citizens with more than 12 amalgam fillings was $300 \mathrm{ng} \mathrm{Hg} / \mathrm{g}$ brain tissue [11], which is well above mercury levels proven to be toxic in vitro on neurons (0.02 -36 ng $\mathrm{Hg} / \mathrm{g})$ (see above).

In another autopsy, individuals with more than 10 amalgams have $504 \mathrm{ng} \mathrm{Hg} / \mathrm{g}$ in their kidney tissues (0-2 amalgams: $54 \mathrm{ng} \mathrm{Hg/g}$ ) and $83.3 \mathrm{ng} \mathrm{Hg} / \mathrm{g}$ in the liver (0-2 amalgams: $17.68 \mathrm{ng} \mathrm{Hg} / \mathrm{g}$ ) [5].

Mercury levels in thyroid- and pituitary glands were $55 \mathrm{ng} \mathrm{Hg} / \mathrm{g}$ and $200 \mathrm{ng} \mathrm{Hg/g}$ respectively and again, these levels correlates significantly with numbers of amalgam fillings [37].

Because the levels found in these studies are only average levels, a significant portion of individuals with dental amalgam have more than twice (standard deviation) these toxic mercury levels in their body tissues. It is important to note that mercury levels found in subcellular fractions like microsomes, mitochondria and other cell compartments even exceed the average levels of the brain samples analysed in these studies [38].

\section{Toxic mercury levels in Alzheimer's disease}

The average mercury load in brain tissues of individuals with Alzheimer's disease was 20 to $178 \mathrm{ng} \mathrm{Hg} / \mathrm{g}$; in some cases the load exceeded up to (236- $698 \mathrm{ng} \mathrm{Hg} / \mathrm{g}$ ). In $15 \%$ of the human brain samples the mercury load was above $100 \mathrm{ng} \mathrm{Hg/g}$ [39-41]. The average mercury load in the pituitary gland was $400 \mathrm{ng} \mathrm{Hg} / \mathrm{g}$ [42]. These levels are again well far above established toxic levels (see above).

\section{Pathological changes, caused by mercury, in most german human brains?}

About $20 \%$ of individuals in the age group of 20 years, $50 \%$ of individuals in the age group of 50 years, and $90 \%$ of people in the age group of 85 years living in Germany show pathological changes in their brains that are typical for Alzheimer's disease [43] and mercury toxicity. This coverage of pathological brain changes caused by very low levels of mercury in experiments and not by low levels of other metals (like lead, iron, aluminum, copper, manganese, chromium, cadmium) $[32,36]$ resembles the frequency of dental amalgam fillings implanted in humans: About $80-90 \%$ of people living in Germany have dental amalgam over decades. It must be noted that about $30-50 \%$ of german people above the age of 85 years have Alzheimer's disease (AD) and there are many hints that mercury plays the major pathogenetic role in AD [44].

\section{Maternal amalgam as the main source of mercury in infant tissues}

Maternal amalgam fillings lead to a significant increase of mercury levels in fetal and infant body tissues including the brain [6]. Furthermore, placental, fetal and infant mercury body burden correlates with the number of amalgam fillings of the mothers [6,45-52].

Mercury levels in amniotic fluid [53] and breast milk [54-56] also significantly correlate with the number of maternal amalgam fillings.

\section{Mercury in infant tissues: Increased risk of neurodevelopmental disorders?}

Drasch et al. found mercury levels of up to $20 \mathrm{ng} \mathrm{Hg} / \mathrm{g}$ in German infant brain tissues which were mainly caused by dental amalgam fillings of their mothers [6]. As described above, mercury levels of $0,02 \mathrm{ng} \mathrm{Hg} / \mathrm{g}$ led to degeneration of axons [32]. Furthermore, the mercury levels found in the brains of infants whose mothers were dental amalgam bearers are sufficient enough to inhibit the function of the important enzyme methionin synthetase $[57,58]$. Methionin synthetase is crucial for 
methylation, a central step for most important metabolic reactions the the body, including the development of the brain, the maturation of nerve cells and the production of neurotransmitters.

Maternal amalgam fillings also increase significantly mercury levels in cord blood $[59,60]$. The risk for delayed neurodevelopment of children was 3.58- times increased when mercury levels in cord blood were higher than $0.8 \mathrm{ng} \mathrm{Hg} / \mathrm{ml}$ [61]. It is important to note that mercury levels of $0.2-5 \mathrm{ng} \mathrm{Hg} / \mathrm{ml}$ cord blood are considered "normal" in Germany [62], thus leaving many infants with mercury levels that may cause neurodevelopmental deficits.

\section{No correlation between mercury in urine or blood and in body tissues}

The SCENIHR report is based on studies which have measured mercury levels in biomarkers such as urine for the assessment of clinical symptoms or mercury body burden. However, the WHO states (1991) that

"Mercury typifies a "retention" toxicity and much of the mercury taken into the body is absorbed by the solid tissues. The amount in urine represents mercury being excreted. However, the main question is how much is being retained in the different body tissues".

It has been shown in experiments with animals and men that in spite of normal or low mercury levels in blood, hair and urine high mercury levels are found in critical tissues such as brain and kidney $[7,13,20,22,25,28,46,63,64]$. A recent study on deceased individuals confirm that there exists no correlation between inorganic mercury levels in urine or blood and mercury levels in brain tissues [37].

Drasch and coauthors have shown that $64 \%$ of individuals occupationally exposed to mercury vapor and having typical clinical signs of mercury intoxication had urine levels of mercury below $5 \mu \mathrm{g} / \mathrm{l}$, which represent the No Observed Adverse Effect Level (NOAEL). The same results were found for mercury levels in blood and hair [65-67].

\section{Paradoxical association between mercury levels in urine and clinical symptoms}

There is even a paradoxical correlation between mercury levels in urine, blood or hair and clinical symptoms: Subjects with highest urine levels of mercury showed best recovery rates from neuropsychological complaints after removing their amalgam fillings [68]. Also children with highest mercury levels in hair showed better performance in developmental tests [69]. Another study indicates that in spite of a significantly higher exposure to mercury in their mothers' womb autistic children had up to 15-times lower mercury levels in their infant hair than healthy children [46]. Furthermore, the lower the mercury levels in infant hair, the higher was the severity of autism [46].

Despite higher mercury body burden, a "amalgam hypersensitivity" group showed slightly lower levels of mercury in their saliva, blood and urine [70]. Even after provocation with the mercury chelator DMPS, the "amalgam hypersensitivity" group excreted in mean only $7,77 \mu \mathrm{g} \mathrm{Hg}$ via urine in $24 \mathrm{~h}$ whereas healthy amalgam bearers excreted 12,69 $\mu \mathrm{g} \mathrm{Hg/24h} \mathrm{[70].}$

Furthermore, studies confirm that the ratio of fecal to urine excretion is 12 to 1 [13]. This proves that the majority of excreted mercury leaves through the bilary transport system of the liver via the fecal route. Urine mercury therefore represents a minor excretory route of less than $8 \%$ of mercury being excreted. Also, urine mercury is a measure of mercury being excreted by the kidney-not a measure of total mercury body burden.

\section{Safety levels for mercury?}

In view of the data presented above, it is impossible to determine any safety levels below which adverse effects can be excluded [71]. SCENIHR used safety limits which were deduced from studies with workers occupationally exposed to mercury. However, these limits cannot be applied to individuals with amalgam fillings and must be critically evaluated:

a) Frequently, mercury exposure of workers in the chlorine-alkali industry is used for comparison although the simultaneous exposure to chlorine considerably diminishes the absorption of mercury into the body tissues of animals by 50-100\% [72].

b) Workers exposed to mercury usually represent a group whose mercury-exposure starts only with adulthood (for about 8 hours a day, 5 days a week), while amalgam bearers can be exposed to mercury in the womb through maternal amalgam fillings during their childhood and until death at a rate of 24 hours per day, 7 days per week.

c) Workers are a selected healthy group, while pregnant women, infants, children and individuals with illnesses (such as multiple sclerosis, autoimmunity, cancer, psychiatric diseases) do not start working at all either due to industrial safety regulations or to early health problems during working.

d) Despite mercury exposure below "safety limits", significant adverse health effects were found in most studies in workers exposed occupationally to mercury, even several years after the exposure had ceased [73-81]. 


\section{Body half-time period of mercury}

SCENIHR state that the body half-time (of mercury) is "20-90 days".

Particularly in the brain, mercury has a significantly longer half-time of more than 17 years [63,64,82-87].

\section{Toxicity of mercury}

SCENIHR did not mention the specific toxicity of mercury vapor coming off dental amalgam fillings. This should be mentioned in a risk analysis:

Mercury has been shown to be 10 times more toxic than lead $(\mathrm{Pb})$ in vitro [88-90]. Mercury is the most toxic non-radioactive element. Mercury vapor is one of the most toxic forms of mercury along with some of the organic mercury compounds. This extraordinary toxicity is also determined by the following properties:

a) Mercury is the only metal representing a volatile gas at room temperature, which is readily absorbed (80\%) by the respiratory system.

b) Mercury vapor from amalgam penetrate into tissues with great ease, because of its monopolar atomic configuration.

c) Once inside the cells, mercury vapor is oxidized to $\mathrm{Hg}^{2+}$, the very toxic form of mercury which binds covalently to thiol groups of proteins inhibiting their biological activity.

d) $\mathrm{Hg}^{2+}$ is more toxic than $\mathrm{Pb}^{2+}$, Cadmium $\left(\mathrm{Cd}^{2+}\right)$ and other metals because it has a higher affinity due to "covalent bond" formation with thiol groups (cysteines in proteins) causing irreversible inhibition. Other metals form reversible bonds with proteins and are therefore less toxic.

e) $\mathrm{Hg}^{2+}$ does not bind tightly enough to the carboxylate groups of natural organic acids (natural chelators like citrate) for its toxicity to be prevented.

f) Chelating agents, like EDTA, which normally inhibit the toxic effect of heavy metals like lead, have no inhibitory effect on the toxicity of mercury or may even increase it $[91,92]$. Other chelating agents (DMPS and DMSA) inhibit the toxic effect of $\mathrm{Cd}^{2+}$ and $\mathrm{Pb}^{2+}$, but not of $\mathrm{Hg}^{2+}$ [93]. DMPS, DMSA or natural chelators like vitamin $C$, glutathione or alpha-lipoic acid are not able to remove mercury from nervous tissues [94]. DMPS or DMSA may even increase the inhibitory activity of $\mathrm{Hg}^{2+}$ and $\mathrm{Cd}^{2}$ +on enzymes but not of $\mathrm{Pb}^{2+}$ [95]. Furthermore, DMPS in animals led to an increase of mercury concentrations in the spinal cord [96].

The toxicity of methylmercury which is bound to cysteine in fish seems to be far lower (only approx. 1/ 20) than methylmercury compounds usually used in experiments [97].
Furthermore, marine fish represents a significant source of selenium and essential omega-3-fatty acids, which are known to protect effectively against mercury toxicity. Nevertheless, methylmercurychloride, which proved to be more toxic than methylmercury in fish, showed less neurotoxicity for the growing nervous system in vivo than did mercury vapor [98].

Investigations by Drasch et al. show similar correlations: The population of a goldmining area, which was exposed to mercury vapor, showed significantly more neurological symptoms of mercury intoxication than a control group which mainly was exposed to methylmercury from fish consumption, despite their mercury levels in hair and plasma being higher compared to the individuals exposed to mercury vapor $[65,66]$. Another study also points to smaller neurotoxicity of methymercury from fish compared to iatrogenic mercury sources (amalgam, thimerosal) [46]. Here, in contrast to the numbers of dental amalgam in the mothers, no correlation between maternal fish consumption during pregnancy and the risk of autism for their children was found.

In summary, mercury vapor coming off dental amalgam or methylmercury derived from amalgam in the gastrointestinal tract has not reacted with anything yet and has the full toxic potential. On the other hand, methylmercury in fish has already reacted with fish proteins and other protective molecules or atoms in fish tissues such as glutathione or selenium, which are enriched in fish. Furthermore, newest studies confirm that most individuals with dental amalgam fillings are exposed to toxic mercury levels $[99,100]$.

\section{Synergistic toxicity of mercury to lead $(\mathrm{Pb})$}

Some scientists try to argue that results gained by animal or cell testing are overestimated and not comparable to the situation of the human body. However, in contrast to test animals in experiments, humans are exposed to many other toxins simultaneously, thus the effects add up or are even synergistic [101,102]. For example, it has been proven that the combination of the Lethal Dose $1 \%$ of mercury $\left(\mathrm{LD} 1_{\mathrm{Hg}}\right)$ together with the LD1 of lead $(\mathrm{Pb})$ results in the death of all animals, so the following toxicological equation can be assumed: LD1 $(\mathrm{Hg})+$ LD1 $(\mathrm{Pb})=$ LD 100 [101].

In this context, it must be considered that modern humans have more mercury and between 10-1,000times more lead in their body tissues than ancient humans.

In other experiments, the addition of aluminumhydroxide (often in vaccines), antibiotics, thimerosal (sometimes in vaccines) and testosterone increased the toxicity of mercury $[108,109]$. The synergistic toxicity of testosterone explain the observation, that much more 
males than females suffers from autism or amyotrophic lateral sclerosis.

\section{No adverse effects through dental amalgam?}

SCENIHR states "It is generally concluded that no increased risk on adverse systemic effects exists and we do not consider that the current use of dental amalgam poses a risk of systemic disease" and "....some local adverse effects are occasionally seen with dental amalgam fillings, but the incidence is low and normally readily managed"

SCENIHR has neglected numerous scientific studies which find significant adverse health effects from dental amalgam:

\section{Cytotoxicity of amalgam in comparison to composites}

SCENIHR compare the toxicity of amalgam with composites. However, in most experiments, even inorganic mercury, which is much less toxic than mercury vapor (because inorganic mercury is not able to penetrate easily into the cells), was proven to be much more toxic than any composite compound: Mercury was shown to be 100-800- fold more toxic than composite components for human cells [110-114].

\section{Genotoxicity, oxidative stress, cancer}

Dental amalgam fillings have been found to cause DNA damage in human blood cells. [115]. Even low levels of inorganic mercury lead to significant DNA damage in human tissue cells and lymphocytes [116]. This effect, which trigger cancer, has been found with mercury levels below those normally causing cytotoxicity and cell death. Furthermore, aberrations of chromosomes can be provoked by amalgam in cell cultures [117]. Amalgam bearers show significantly increased oxidative stress in saliva $[118,119]$ and blood $[120,121]$. The increase of oxidative stress correlates with the numbers of amalgam fillings. Mercury levels normally seen in tissues of individuals with amalgam fillings lead to increased oxidative stress and reduction of glutathione levels, thus inducing cellular damage $[33,34]$. Significantly elevated mercury levels have also been observed in breast cancer tissues [122]. Mercury deposited in the tissue is mostly bound to selenium, which means that the this selenium is no longer available for the body. Therefore, amalgam may aggravate a latent deficiency of selenium, particularly in countries with suboptimal selenium supply (e.g. in Central Europe) [123,124].

\section{Antibiotic resistance}

It has been shown that mercury from dental amalgam can induce mercury resistant bacteria [125-127]. This leads to a general antibiotic resistance in oral bacteria and in other body sites [127], which is particularly true when the antibiotic resistance genes are contained within the same mobile element as the mercury resistance operon $[128,129]$. Mercury resistance is common in human oral bacteria [130,131]. Monkeys with dental amalgam also showed an increase in antibiotic resistant bacteria in their stools $[127,132]$.

\section{Penetration of amalgam in tooth bone and jaw}

Experiments on monkeys and sheep have shown that mercury from amalgam penetrates easily into the dentin roots as well as into the jaw bone $[25,26]$. The fact that this was also shown for humans [133] confirms an alternative route of mercury exposure caused by amalgam.

\section{Skin}

There is a correlation between atopic eczema and IgElevels and the body burden of mercury [134]. Amalgam fillings can induce lichenoid reactions [135-139]. In more than $90 \%$ of the cases, these lesions have been found to recover upon removal of amalgam, no matter whether an allergy patch test was positive or not. Granulomatosis improved likewise [140]. Also, other forms of dermatitis seem to be related to dental amalgams $[141,142]$.

\section{Autoimmune disorders and mercury hypersensitivity}

Constant low-dose mercury exposure, as is common in amalgam bearers, has been considered a possible cause for certain autoimmune diseases, e.g. multiple sclerosis, rheumatoid arthritis or systemic lupus erythematosus (SLE) [135,143-152]. These effects occur with exposure below mercury safety limits [153]. Recent research has shown that mercury and ethylmercury have the ability to inhibit the first step (phagocytosis) in the innate and acquired immune response of humans at very low levels [154]. This shows that mercury exposures quite below the average exposure through amalgam exposure can cause disruption of the immune system at all ages.

\section{Only "rare cases of proven allergic reactions"?}

SCENIHR only accept the "proof" of allergic reactions to amalgam, which is a positive cutaneous patch test. However, it has been shown that in more than $90 \%$ of the cases with mucosal reactions these lesions have been found to recover by removal of amalgam, no matter whether a cutaneous patch test was positive or not $[137,139,140]$. Therefore the relevance of the cutaneous patch test in detecting sensitivity or allergy to mercury implanted in the oral cavity without any epicutaneous contact has been severely questioned [155].

The results with another validated test system reveal that there are more than just "rare cases" with 
immunological complaints due to dental amalgam [148,150,152,156-162].

There may also be a correlation between atopic eczema, IgE-levels and the body burden of mercury, which is also not detected by means of cutaneous patch tests [134].

Because mercury from maternal dental amalgam is one of the main sources of mercury body burden in fetal and infant tissues, postnatal atopic eczema disappear after mercury detoxification of the infants [163].

\section{Heart diseases}

Mercury may cause hypertension and myocardial infarction [164].

Significant mercury accumulation (22,000 times higher than controls) has been found in heart tissues with a form of heart insufficiency [165].

\section{Urinary system}

SCENIHR cited only one review performed by a dentist and published in a dental trade journal [166] as well as 5-7 year studies on initially healthy children, also performed mainly by dentists, to back up their argument that "there is no evidence that dental amalgam fillings affect kidney function in humans". However, there are many other studies suggesting quite the opposite:

In animal experiments, an impairment of renal functions due to amalgam fillings has been observed $[23,146,167]$. Humans with amalgam fillings show more signs of tubular and glomerular damage when compared to individuals without dental amalgams [15]. The frequently mentioned children amalgam trial study found first signs of kidney damage (microalbuminuria) [168] even after only 5 years of amalgam exposure.

\section{Alzheimer's disease (AD)}

SCENIHR questioned that mercury may contribute to the development of AD. As a proof of this statement they cited only one study [41] published in the trade journal of the world-wide leading American Dental Association (ADA) [102]. In contrast, other studies have shown that mercury play a major pathogenetic role in $\operatorname{AD}[108,109,169,170]$. A new systematic analysis of the literature regarding the role of mercury in $\mathrm{AD}$ found a significant association [124].

\section{Parkinson's disease (PD)}

Heavy metals have long been suspected to be a cause of $\mathrm{PD}$, with several studies showing a relation, including epidemiological studies [171-180]. Elemental mercury has induced PD [175], and in a case report, the condition of PD substantially improved after treatment with a mercury chelator [173] and remained unchanged during a 5-year follow-up period [173]. In another study, significantly elevated blood mercury levels were found in 13 of 14 patients with PD compared to healthy controls [172]. This supports the conclusion of a previous study which found a correlation between blood mercury levels and PD [176]. Another study found significantly higher amalgam exposure in individuals with PD compared to healthy controls [179].

\section{Adverse health effects in dental staff?}

SCENIHR state that "the incidence of reported adverse effects [in dental staff and dentists] is very low".

A simple literature research reveals quite the opposite: Dentists working with amalgam have an increased mercury exposure $[17,181,182]$. In most studies available, mercury exposure in dental clinics resulted in significant adverse health effects in dental workers. In some studies, the clinical outcome was not correlated with mercury levels in urine or blood, and some authors falsely concluded that mercury was therefore not the cause of the adverse effects. However, this is not scientific since urine- or blood mercury levels did not correlate with tissue levels (see above). Lindbohm et al. (2007) found a two-fold increased risk for miscarriage through occupational exposure to mercury (OR 2,0; 95\% CI 1,0- 4,1). The effect from mercury exposure was stronger than from exposure to acrylate compounds, disinfectants or organic solvents [199].

Even 30 years after cessation of mercury exposure, dental nurses showed significant adverse health effects [200]. In spite of the fact that $85 \%$ of the dentists and dental technicians tested showed mercury related toxicities in both behavior and physiological parameters, and $15 \%$ showed increased mercury induced neurological deficits with polymorphism of the CPOX4 gene $[186,188,201]$, SCENIHR still maintain that amalgams do not cause any significant medical problems in dental workers, because urine and blood levels are below "safety limits".

\section{Infertility}

SCENIHR stated that "There is no evidence of any association between amalgam restorations and either male or female fertility or obstetric parameters". As a proof of this statement, SCENIHR cited just one study, which examines only semen parameters in men. However, other studies point to the opposite direction, especially when examining women:

Female dental assistants exposed to amalgam showed a higher rate of infertility [198]. Women with more amalgam fillings or increased mercury levels in urine (after mobilization with DMPS) had a higher incidence of infertility [202-204]. Heavy metal detoxification led to spontaneous pregnancies in a considerable part of the infertile patients [203]. Exposure to mercury also lead to 
decreased male fertility [205-207]. A Norwegian study which is often cited as a proof that mercury exposure in dental clinics does not cause infertility suffers from methodological flaws insofar as only women were included who had already given birth to at least one child. Women without children were excluded. Such a study certainly cannot answer the question if working with amalgam leads to infertility or not. Moreover, the exposure time to amalgam was not calculated and thus not included as a covariate into the study.

\section{Multiple Sclerosis (MS)}

A 7,5-fold increased level of mercury was found in the cerebrospinal fluid (CSF) of MS patients [208]. It would be difficult to speculate that the presence of this increase in the CSF would not at least exacerbate the problems associated with MS or any other neurological disease. The prevalence of MS has been shown to be correlated with the prevalence of caries $[209,210]$ and the prevalence of amalgam $[211,212]$. Several MS epidemics occurred after acute exposure to mercury vapor or lead [213]. In animal models inorganic mercury caused a loss of Schwann cells which build the myelin sheaths and stabilize the axons of neurons [214]. Autoimmune pathogenesis, including antibodies against myelin basic protein (MBP), can be provoked by mercury and by other heavy metals [148].

MS patients who had their amalgam fillings removed showed fewer depressions, less aggression and less psychotic and compulsory behaviors when compared to a group of MS patients with amalgam fillings [215]. They also had significantly lower levels of mercury in blood [216]. After amalgam removal, pathological oligoclonal bands in the CSF disappeared in MS patients [217]. Removal of dental amalgam also led to a recovery in a significant proportion of MS patients [147]. A retrospective study on 20,000 military individuals revealed a significantly higher risk for MS in individuals with more amalgam fillings [218]. This risk was underestimated, because the study cohort which was selected by means of medical examination consisted exclusively of individuals with good health at the time of joining the military [218]. Another problem occurring in some studies is the absence of documentation of the dental status before or at the time of the onset of multiple sclerosis. In spite of these limitations [219] a reanalysis found a 3.9- fold increased risk for multiple sclerosis in individuals with amalgam compared to individuals with no amalgam. A recent systematic review also found an increased risk for MS caused by dental amalgam in spite of the fact that most studies did not use proper amalgam-free controls [220].

\section{Amyotrophic Lateral Sclerosis (ALS)}

SCENIHR state that "there is no evidence for a relationship between Amyotrophic Lateral Sclerosis (ALS) and mercury"

In contrast to the statement of SCENIHR, there are many studies which suggest that mercury may play a pathogenetic role in ALS:

Mercury vapor is absorbed by motor neurons [221] where it leads to increased oxidative stress. In experiments, mercury vapor was found to promote motor neuron diseases such as ALS [222-226]. It was proofed that mercury enhances glutamate toxicity in neurons, which is one factor in ALS. Case reports show a correlation between accidental mercury exposure and ALS $[227,228]$. There is a reported case of a Swedish woman with more than 34 amalgam fillings who suffered from ALS. After removal of these fillings she recovered [229]. A retrospective study reported a statistically significant association between an increased number of amalgam fillings and the risk of motor neuron diseases [218].

\section{"Amalgam disease" and markers of sensitivity}

Among the most frequently reported symptoms due to amalgam fillings are: Chronic fatigue, headache, migraine, increased susceptibility to infections, muscle pain, lack of concentration, digestion disorders, sleeping disorders, low memory capacity, joint pain, depression, heart sensations, vegetative disregulation, mood disorders and many more [161,215,216,230-234].

Until recently it was not possible to differentiate between "amalgam-sensitive" and "amalgam-resistant" persons by their mercury levels in blood or urine or an epicutaneous test (patch test) $[9,21]$. However, it could be shown that subjects could react to a mercury patch test with psychosomatic complaints, although there was no allergic reaction of the skin [235]. In addition, neutrophil granulocytes in amalgam-sensitive subjects react differently compared to those in amalgam-resistant subjects [236] and different activities of the superoxide dismutase could be found [237].

\section{Increased susceptibility to mercury and amalgam}

SCENIHR did not mentioned any susceptibility parameters which make a significant proportion of the population more susceptible to mercury from dental amalgam:

a) Abnormal porphyrine profiles due to mercury exposure It is known that mercury exposure leads to aberrant urine porphyrine profiles in dentists [238] and autistic children and that this aberrancy was reversed by treating these children with a mercury chelator [239-241].

A genetic polymorphism of coproporphyrinoxidase (CPOX4) $[188,201]$ leads to increased susceptibility to 
mercury and thus to a higher risk for neurobehavioral complaints [242].

The critical question here is the effect of mercury vapor exposure on brain porphyrine profiles since an aberrancy in brain heme has been associated with the inability to remove beta-amyloid protein from brain cells, which in turn may lead to Alzheimer's disease [243].

It should be noted that porphyrins lead to heme, and heme is critical for several biochemical mechanisms: (i) heme is the oxygen carrying cofactor for haemoglobin, (ii) heme is a critical cofactor for the P450 class of enzymes that are responsible for detoxifying xenobiotics from the body, (iii) heme is a necessary cofactor for one of the complexes in the electron transport system of mitochondria and therefore ATP-synthesis.

Therefore, mercury inhibition of heme production could have a multitude of secondary effects causing human complaints and illnesses.

In spite of the fact that $85 \%$ of the dentists and dental technicians tested showed mercury related toxicities in both behavior and physiological parameters, and 15\% showed an increase of mercury induced neurological deficits with polymorphism of the CPOX4 gene, organized dentistry and SCENIHR still maintain that amalgams do not cause any significant medical problems because the urine and blood levels are below safety limits.

\section{b) Brain derived neurotrophic factor}

Another genetic polymorphism of the brain derived neurotrophic factor (BNDF) increases also the susceptibility to very low level mercury exposure $[186,187]$.

\section{c) Apolipoprotein E diversity}

It could be shown that amalgam sensitive persons are significantly more likely to be carriers of the apolipoprotein E4-allel (APO-E4) than symptom free controls and that they are less likely to carry the APO-E2 [231,234]. APO-E4 is known to be the major genetic risk factor for Alzheimer's disease, whereas APO-E2 decreases the risk. It has been postulated that this is due to the difference in capacity to remove heavy metals from the cerebrospinal fluid $[44,92,102,124,231,234,244]$. APO-E2 possesses two cysteines with metal binding sulfhydryl-groups whereas APO-E4 does not have any cysteine residues.

\section{d) Glutathione metabolism}

Reduced glutathione (GSH) is the main natural chelator for heavy metals in the body due to its sulfhydryl-containing cysteine. Only mercury, which is bound to glutathione (or selenium), is capable of leaving the body via urine or biliary excretion. Thus, a high level of glutathione is crucial for mercury metabolism. It has been described that polymorphisms in genes leading to impaired GSH production cause higher retention of inorganic and organic mercury in the body. Other factors which may increase susceptibility to low dose mercury exposure, e.g. low levels of selenium, abnormal reaction of neutrophil granulocytes, activity of super oxide dismutase, D4-receptor positive methionine synthetase and impaired methionine transulfurationand methylation pathways (about $15 \%$ of the population), led to decreased mercury protecting agents, like Sadenyl-methionine, cysteine, GSH and metallothionine [44,245-247].

\section{Improvement after removal of amalgam}

Significant improvement of health and above mentioned diseases (including Multiple Sclerosis and other autoimmune diseases) have been reported after amalgam removal (in most studies with elaborate protective measures to minimize mercury exposure) $[68,147,149$, $150,159,161,217,230,233,234,248-251]$.

\section{No neurodevelopmental disorders through mercury?}

SCENIHR stated that "There is no evidence of a causal relationship between dental amalgam and autism" and "... that no link has been yet established between vaccines, thimerosal and autism".

Nonetheless other authors come to opposite conclusions:

“...mercury exposure altered cell number and cell division; these impacts have been postulated as modes of action for the observed adverse effects in neuronal development. The potential implications of such observations are evident when evaluated in context with research showing that altered cell proliferation and focal neuropathologic effects have been linked with specific neurobehavioral deficits (e. g., autism)." [252]

Cheuk and Wong (2006) in patients diagnosed with attention-deficit hyperactivity disorder and Desoto and Hitlan (2007) in patients diagnosed with autistic disorders found significant elevations in blood mercury levels in comparison with controls [253,254]. Adams et al. (2007) observed significant increases in the mercury levels of baby teeth in infants with autistic disorders in comparison with controls [255]. Mercury in baby teeth mirrors mercury exposure in the womb.

Recent brain pathology studies have revealed elevations in mercury levels and mercury-associated oxidative stress markers in patients diagnosed with autistic disorders. The level of mercury in the urine of autistic 
children shows an increase of 3-5 times after appropriate treatment with the mercury chelator DMSA compared to healthy children [259]. Autistic children also excrete higher concentrations of coproporphyrine which is specific for mercury intoxication [239,240,260,261]. Detoxification of mercury with DMSA normalizes the abnormal coproporphyrin levels in autistic children $[239,240]$ and led to improvement of symptoms [262]. Additionally, experimental as well as epidemiological studies indicate that mercury exposure is responsible for autism or a deterioration of the disease. Prenatal exposure to maternal amalgam [46,263], maternal thimerosal $[46,264]$ and postnatal sources (mercury from vaccines for the child) together with a genetic sensitivity may trigger autism. In animal experiments vaccination with thimerosal led to symptoms similar to autism [265]. Epidemiological studies confirm a significant association between low-dose mercury exposure and neurodevelopmental disorders [266][267][268][269][270][271]. Autistic children show decreased levels of the natural mercury chelator glutathione [272]; it is known that mercury is capable of causing this phenomen [273]. In some preliminary therapy studies with chelation therapy led to improvement of symptoms [263]. The Autism Research Institute therefore lists chelation as the most effective therapeutic approach among 88 therapies including 53 medications [274].

Zahir et al. (2005) described that the access of mercury

“...to man through multiple pathways air, water, food, cosmetic products and even vaccines increase the exposure. Fetuses and infants are more susceptible to mercury toxicity. Mothers consuming diet containing mercury pass the toxicant to fetuses and to infants through breast milk. Decreased performance in the areas of motor function and memory has been reported among children exposed to presumably safe mercury levels [...] Mercury has been found to be a causative agent of various sorts of disorders, including neurological, nephrological, immunological, cardiac, motor, reproductive and even genetic. Recently heavy metal mediated toxicity has been linked to diseases like Alzheimer's, Parkinson's, Autism, Lupus, Amyotrophic lateral sclerosis, etc."[275].

Some studies which found no associations between mercury exposure and autism have severe methodical flaws [245].

\section{Severe methodical flaws in studies cited by SCENIHR as a proof of the safety of dental amalgam}

In order to study toxic effects it is necessary to compare at least two samples: one that was exposed to the substance in question and one that was not. One of the main problems in most of the amalgam studies is that the vast majority did not incorporate a true control group that had never been exposed to dental amalgam. Even when comparing samples with and without dental fillings, the sample without dental fillings had been exposed to dental amalgam earlier in life. The studies cited frequently not only by SCENIHR as a proof of the putative harmlessness of amalgam do not use "proper" non-amalgam control groups. There is a prominent example to describe:

The Swedish twin study [276] actually only compared 57 twin-pairs in a co-twin analysis, and not 587 as mentioned by the authors and many governmental institutions. As the average age of the sample was 66 years, $25 \%$ had no teeth at the time of investigation, many had missing teeth and an unknown number had crowns using other dental materials. Root fillings with amalgam and amalgam fillings under crowns were not calculated. As an allegedly "non-amalgam" group, they were compared with individuals who still had teeth with amalgam fillings. The authors found that individuals with more amalgam fillings (which means also more own teeth) had a better health status. It is fair to assume that individuals with few or no teeth or teeth that have been restored with crowns or bridges had probably had dental amalgam previously. As mercury accumulates in body tissues, this "amalgam free group" might have a higher mercury body burden than the "amalgam group" with currently existing amalgam fillings.

SCENIHR also cited Zimmer et al. (2002) as a proof of the safety of amalgam. But this study compared two groups exposed to amalgam (all female, one group of patients who claimed to be suffering from symptoms they related to their amalgam fillings and the other group which did not report any association between complaints and their amalgam) in terms of mercury levels in body fluids and psychometric tests. The mean number of amalgam fillings was identical in both groups. They found equal mercury levels in both amalgam groups. Zimmer et al. (p. 210) conclude: "Thus, mercury released from amalgam fillings was not a likely cause of complaints reported by the amalgam sensitive subjects" [21]. It is not clear why these authors come to such a conclusion. Furthermore it is known from animal experiments and pharmacological studies that individuals given equal amounts of a toxin might react differently. An example for this is that not every smoker develops lung cancer, although smoking is now accepted as a main cause for cancer.

\section{"Children amalgam trials"}

SCENIHR based their statement about the safety of dental amalgam also on two children amalgam trials. These studies show severe methodical flaws: 
In two randomised trials on children it was evaluated whether mercury containing dental amalgam had adverse neuropsychological or renal effects [277,278]. Healthy children were randomised to either amalgam or composite surface restoration. Two children in the amalgam group died (one possibly by committing suicide) and were excluded from the study.

Power calculation (binomial - adverse event versus no event) indicates that psychological illness, having prevalence of $6.7 \%$ in the composite-treated children, would have to have had a prevalence of at least $14.5 \%$ in the amalgam group to have an $80 \%$ chance of being proven statistically (observed was 9.0\%). Similarly for neurological illness, observed prevalences in the composite group ( $0.4 \%$ composite, $1.5 \%$ amalgam) would have needed at least $4.5 \%$ prevalence in the amalgam group to be significant. From the authors it was concluded that "there is no reason to discontinue use of mercury amalgam" [277] and that "dental amalgam [...] emits small amounts of mercury vapor" [278].

The first conclusion is a classic error: Due to its lack of power, the study provides false reassurance that mercury is 'safe'. To effectively evaluate the effect sizes seen, the trial should have been much larger (1500-2500/ group).

Urine porphyrin profiles and markers of oxidative stress, which are elevated in individuals with dental amalgam $[19,119]$ were not measured. Also, genetic polymorphism, which increase the susceptibility to mercury, like BDNF-Polymorphism [186,188] and Glutathion-S-Transferase gene polymorphism [279] were not measured either. Furthermore, the real exposure level of mercury (mercury vapor emitted in the oral cavity) was not determined, which questions the ethics of such a study. Research has demonstrated that the emission of mercury vapor was much higher than what has been "estimated" by dentists. Chew et al. (1991) showed that $43.5 \mathrm{microgram} / \mathrm{cm}^{2} /$ day mercury was released from a "non-mercury releasing amalgam" and this remained constant over the study period of 2 years [280].

Mean mercury urine levels were significantly higher in the amalgam groups $[277,278]$, although in years 3 to 7 the levels of mercury in the urine of the amalgam bearers continuously dropped until they approached the levels of the amalgam free children [278]. But restorative treatment was used in years 6 and 7, which should have increased or at least maintained the urine mercury levels. This needed explaining. In the Chew study above [280], the amount of mercury released was steady for 2 years (the length of the study). It is known that amalgam do not stop releasing mercury vapor within 7 years. The question therefore is what the drop was caused by after year 2? Urine mercury levels are a measure of the amount of mercury being excreted via this route. Therefore, after two years of mercury exposure the route of kidney excretion of mercury appears to be becoming less effective. This is consistent with the wellknown fact that increased mercury exposure inhibits its own excretion. It has been published and verified that over $90 \%$ of mercury excreted by humans leaves through the biliary transport system of the liver and is excreted in the feces, not in the urine [13]. The conclusion of Bellinger et al. [277] that "there is no reason to discontinue use of mercury amalgam" is amazing, because possible adverse effects may need more than five years of mercury exposure to develop. If mercury is involved in the pathogenesis of Alzheimer's disease, the disease may need up to 50 years to be diagnosed clinically [44].

One of the included criteria for the two studies was "no interfering health conditions" including neurodevelopmental disorders. The Centers for Disease Control and Prevention (CDC) in Atlanta (USA) reports that 1 in 6 American children have a neurodevelopmental disorder. However, above mentined papers conclude that amalgams should remain a viable clinical option in dental restorative treatment [278] and they did not exclude use on children with neurodevelopmental disorders exactly the type of child, however, which they excluded from their studies. As mercury exposure during pregnancy may be the prime cause of neurodevelopmental disorders $[46,61,245]$, this conclusion from the children amalgam is unsafe for the public.

\section{Amalgam for mercury pollution}

There has been an alarmingly increase of mercury in our environment [281] and human bodies [282] over the last decades. The UNEP reports on a 3-5 fold increase over the last 25 years [281].

In the European Union (EU) the usage of amalgam amounts to 120 tons yearly. Dentists are the $2^{\text {nd }}$ largest user group in the EU [283,284].

Recent calculations done by Hylander [284,285] show that there are 40 tons of mercury in teeth with dental amalgam of Swedish people, which results to the excretion of $100 \mathrm{~kg}$ of mercury per year in wastewater. 1300 to 2200 tons of mercury in dental amalgam is present in the teeth of citizens in the EU (27 countries) [284], and for the USA the respective figures are about 1000 tons. In the US, dental amalgam is the 3rd most significant source of environmental mercury [286]. In contrast to the EU, removed amalgam is not separated from the wastewater of dental clinics in the US. But even in most EU-countries, where such separators are in use, parts of the dental amalgam leaks into the environment [284].

This mercury from dental amalgam (i.e. mercury emissions from dental clinics in wastewater, excreted mercury emissions from amalgam in living individuals, 
mercury emissions from elevated mercury deposits in tissues of deceased and cremated humans with dental amalgam) enter into the environment. When including environmental costs into the economic calculation (except costs from amalgam related diseases), amalgam is the most costly dental material as was shown by Hylander and Godsite [283].

\section{The role of organized dentistry in SCENIHR and in defending amalgam}

The SCENIHR amalgam expert group consisted of one engineer (chairman), four dentists, a toxicologist and two veterinarians. The chairman has tight contacts to the industry. No experts for medicine or environmental medicine were included. One must wonder why it were the dentists who represented the strongest party in SCENIHR.

Due to their education and clinical experience, dentist are not able to judge medical systemic adverse side effects caused by dental amalgam, like multiple sclerosis, autism, autoimmunity, Alzheimer's disease, psychiatric diseases etc. Usage of dental amalgam may increase worldwide (increasing caries epidemic in undeveloped countries which constitute the highest percentage of the world`s population ). Today, dental organisations are the only trade group of health professionals who endorse the use of a product that is primarily made of mercury. Every amalgam patent has been produced according to dental organisations specifications $[287,288]$. This may indeed be a critical point, because organized dentistry, which has always support the use of dental amalgam, are responsible for adverse side effects $[287,288]$. Therefore, the strategies of organized dentistry used to influence science and politics over the last decades [287-290] may be analogous to other well known topics with existing conflicts of interest, where effective measures have been applied to influence science and politics regarding dangerous products [291-295].

\section{Competing interests}

The author declare that he have no competing interests.

Received: 23 March 2010 Accepted: 13 January 2011

Published: 13 January 2011

\section{References}

1. Scientific Committee on Emerging and Newly Identified Health Risks (SCENIHR): The safety of dental amalgam and alternative dental restoration materials for patients and users. Europaen Commision 2008, 1-74[http://ec.europa.eu/health/ph_risk/committees/04_scenihr/docs/ scenihr_o_016.pdf].

2. Barregard J, Svalander C, Schutz A, Westberg G, Sällsten G, Blohmé I, Mölne J, Attman PO, Haglind P: Cadmium, mercury, and lead in kidney cortex of the general Swedish population: a study of biopsies from living kidney donors. Environ Health Perspect 1999, 107:867-871.
3. Becker K, Kaus S, Krause C, Lepom P, Schulz C, Seiwert M, Seifert B: German Environmental Survey 1998 (GerES III): environmental pollutants in blood of the German population. Int J Hyg Environ Health 2002, 205:297-308.

4. Becker K, Schulz C, Kaus S, Seiwert M, Seifert B: German Environmental Survey 1998 (GerES III): Environmental pollutants in the urine of the German population. Int J Hyg Environ Health 2003, 206:15-24.

5. Drasch G, Schupp I, Riedl G, Günther G: Einfluß von Amalgamfüllungen auf die Quecksilberkonzentration in menschlichen Organen. Dtsch Zahnärztl Z 1992, 47:490-496.

6. Drasch G, Schupp I, Hofl H, Reinke R, Roider G: Mercury burden of human fetal and infant tissues. Eur J Ped 1994, 153:607-610.

7. Drasch G, Wanghofer E, Roider G: Are blood, urine, hair, and muscle valid bio-monitoring parameters for the internal burden of men with the heavy metals mercury, lead and cadmium? Trace Elem Electrolyt 1997, 14:116-123.

8. Eggleston DW, Nylander M: Correlation of dental amalgam with mercury in brain tissue. J Prosth Dent 1987, 58:704-707.

9. Gottwald B, Traencker I, Kupfer J, Ganss C, Eis D, Schill WB, Gieler U: "Amalgam disease" - poisoning, allergy, or psychic disorder? Int J Hyg Environ Health 2001, 204:223-229.

10. Guzzi G, Grandi M, Cattaneo C: Should amalgam fillings be removed? Lancet 2002, 360:2081

11. Guzzi G, Grandi M, Cattaneo C, Calza S, Minoia C, Ronchi A, Gatti A, Severi G: Dental amalgam and mercury levels in autopsy tissues: food for thought. Am J Forensic Med Pathol 2006, 27:42-45.

12. Levy M, Schwartz S, Dijak M, Weber JP, Tardif R, Rouah F: Childhood urine mercury excretion: dental amalgam and fish consumption as exposure factors. Environ Res 2004, 94:283-290.

13. Lorscheider FL, Vimy MJ, Summers AO: Mercury exposure from "silver" tooth fillings: emerging evidence questions a traditional dental paradigm. FASEB Journal 1995, 9:504-508.

14. Kingman A, Albertini T, Brown LJ: Mercury concentrations in urine and whole blood associated with amalgam exposure in a US military population. J Dent Res 1998, 77:461-471.

15. Mortada WI, Sobh MA, El-Defrawy MM, Farahat SE: Mercury in dental restoration: is there a risk of nephrotoxicity? J Nephrol 2002, 15:171-176.

16. Nylander M: Mercury in pituitary glands of dentists. Lancet 1986, 22:442.

17. Nylander M, Weiner J: Mercury and selenium concentrations and their interrelations in organs from dental staff and the general population. $\mathrm{Br}$ $J$ Ind Med 1991, 48:729-734.

18. Nylander M, Friberg L, Lind B: Mercury concentrations in the human brain and kidneys in relation to exposure from dental amalgam fillings. Swed Dent J 1987, 11:179-187.

19. Pizzichini M, Fonzi M, Giannerini M, Mencarelli M, Gasparoni A, Rocchi G, Kaitsas $V$, Fonzi L: Influence of amalgam fillings on $\mathrm{Hg}$ levels and total antioxidant activity in plasma of healthy donors. Sci Total Environ 2003, 301:43-50.

20. Weiner JA, Nylander M: The relationship between mercury concentration in human organs and different predictor variables. Sci Tot Environ 1993, 138:101-115.

21. Zimmer $H$, Ludwig $H$, Bader M: Determination of mercury in blood, urine and saliva for the biological monitoring of an exposure from amalgam fillings in a group with self-reported adverse health effects. Int J Hyg Environ Health 2002, 205:205-211.

22. Danscher G, Hørsted-Bindsley P, Rungby J: Traces of mercury in organs from primates with amalgam fillings. Exp Mol Pathol 1990, 52:291-299.

23. Galic N, Prpic-Mehicic G, Prester LJ, Blanusa M, Krnic Z, Ferencic Z: Dental amalgam mercury exposure in rats. Biometals 1999, 12:227-237.

24. Galic N, Prpic-Mehicic G, Prester LB, Krnic Z, Blanusa M, Erceg D: Elimination of mercury from amalgam in rats. J Trace Elem Med Biol 2001, 15:1-4.

25. Hahn LJ, Kloiber R, Vimy MJ, Takahashi Y, Lorscheider FL: Dental "silver" tooth fillings: a source of mercury exposure revealed by whole-body image scan and tissue analysis. FASEB Journal 1989, 3:2641-2646.

26. Hahn LJ, Kloiber R, Leininger RW, Vimy M, Lorscheider FL: Whole-body imaging of the distribution of mercury released from dental fillings into monkey tissues. FASEB Journal 1990, 4:3256-3260.

27. Lorscheider FL, Vimy MJ: Mercury exposure from "silver" fillings. Lancet 1991, 337:1103. 
28. Vimy MJ, Takahashi Y, Lorscheider FL: Maternal-fetal distribution of mercury $(203 \mathrm{Hg})$ released from dental amalgam fillings. Am J Physiol 1990, 258:939-945

29. Heintze U, Edwardsson S, Derand T, Birkhed D: Methylation of mercury from dental amalgam and mercuric chloride by oral streptococci in vitro. Scand J Dent Re 1983, 91:150-152.

30. Leistevuo J, Leistevuo T, Helenius H, Pyy L, Osterblad M, Huovinen P, Tenovuo J: Dental amalgam fillings and the amount of organic mercury in human saliva. Caries Res 2001, 35:163-166.

31. Yannai S, Berdicevsky I, Duek L: Transformations of inorganic mercury by Candida albicans and Saccharomyces cerevisiae. Appl Environ Microbiol 1991, 57:245-247.

32. Leong CCW, Syed NI, Lorscheider FL: Retrograde degeneration of neurite membrane structural integrity of nerve growth cones following in vitro exposure to mercury. Neuro Report 2001, 12:733-737.

33. Olivieri G, Brack C, Muller-Spahn F, Stähelin HB, Herrmann M, Renard P, Brockhaus M, Hock C: Mercury induces cell cytotoxicity and oxidative stress and increases beta-amyloid secretion and tau phosphorylation in SHSY5Y neuroblastoma cells. J Neurochem 2000, 71:231-236.

34. Olivieri G, Novakovic M, Savaskan E, Meier F, Baysang G, Brockhaus M, Müller-Spahn F: The effects of ß-Estradiol on SHSY5Y neuroblastoma cells during heavy metal induced oxidative stress, neurotoxicity and ßAmyloid secretion. Neuroscience 2002, 113:849-855.

35. Pendergrass JC, Haley BE: Mercury-EDTA Complex Specifically Blocks Brain-Tubulin-GTP Interactions: Similarity to Observations in Alzheimer's Disease. In Status Quo and Perspective of Amalgam and Other Dental Materials. International Symposium Proceedings. Edited by: Friberg LT, Schrauzer GN. Stuttgart: Thieme Verlag; 1995:98-105.

36. Pendergrass JC, Haley BE: Inhibition of brain tubulin-guanosine $5^{\prime}$ triphosphate interactions by mercury: similarity to observations in Alzheimer's diseased brain. In Metallons on Biological systems. Edited by: Sigel A, Sigel H. New York: Dekker; 1997:461-478.

37. Björkman L, Lundekvam BF, Laegreid T: Mercury in human brain, blood, muscle and toenails in relation to exposure: an autopsy study. Environ Health 2007, 11:6:30.

38. Wenstrup D, Ehmann WD, Markesbery WR: Trace element imbalances in isolated subcellular fractions of Alzheimer's disease brains. Brain Research 1990, 533:125-31.

39. Ehmann WD, Markesbery WR, Alauddin M, Hossain TIM, Brubakern EH: Brain trace elements in Alzheimer's disease. Neurotoxicology 1986, 7:197-206.

40. Thompson CM, Markesbery WR, Ehmann WD, Mao YX, Vance DE: Regional brain trace-element studies in Alzheimer's disease. Neurotoxicology 1988, 9:1-8.

41. Saxe SR, Wekstein MW, Kryscio RJ, Henry RG, Cornett CR, Snowdon DA, Grant FT, Schmitt FA, Donegan SJ, Wekstein DR, Ehmann WD, Markesbery WR: Alzheimer's disease, dental amalgam and mercury. J Am Dent Ass 1999, 130:191-199.

42. Cornett CR, Ehmann WD, Wekstein DR, Markesbery WR: Trace elements in Alzheimer's disease pituitary glands. Biol Trace Element Res 1998, 62:107-114

43. Braak H: Neuroanatomy of Alzheimer's disease. Alzheimer's Disease Review 1997, 3:235-47.

44. Mutter J, Naumann J, Sadaghiani C, Schneider R, Walach H: Alzheimer Disease: Mercury as a pathogenic factor and apolipoprotein $\mathrm{E}$ as a moderator. Neuro Endocrinol Lett 2004, 25:275-283.

45. Ask K, Akesson A, Berglund M, Vahter M: Inorganic mercury and methylmercury in placentas of Swedish women. Environ Health Perspect 2002, 110:523-526.

46. Holmes AS, Blaxill MF, Haley BE: Reduced levels of mercury in first baby haircuts of autistic children. Int J Toxicol 2003, 22:277-85.

47. Morgan DL, Chanda SM, Price HC, Fernando R, Liu J, Brambila E, O'Connor RW, Beliles RP, Barone S Jr: Disposition of inhaled mercury vapor in pregnant rats: maternal toxicity and effects on developmental outcome. Toxicol Sci 2002, 66:261-273.

48. Takahashi Y, Tsuruta S, Hasegawa J, Kameyama Y, Yoshida M: Release of mercury from dental amalgam fillings in pregnant rats and distribution of mercury in maternal and fetal tissues. Toxicology 2001, 163:115-126.

49. Takahashi Y, Tsuruta S, Arimoto M, Tanaka H, Yoshida M: Placental transfer of mercury in pregnant rats which received dental amalgam restorations. Toxicology 2003, 185:23-33.
50. Vahter M, Akesson A, Lind B, Bjors U, Schutz A, Berglund F: Longitudina study of methylmercury and inorganic mercury in blood and urin of pregnant and lactating women, as well as in umbilical cord blood. Environ Res 2000, 84:186-194.

51. Yoshida M, Satoh M, Shimada A, Yamamoto E, Yasutake A, Tohyama C: Maternal-to-fetus transfer of mercury in metallothionein-null pregnant mice after exposure to mercury vapor. Toxicology 2002, 175:215-222.

52. Yoshida M, Watanabe C, Satoh M, Yasutake A, Sawada M, Ohtsuka Y, Akama Y, Tohyama C: Susceptibility of Metallothionein-Null Mice to the Behavioural Alterations Caused by Exposure to Mercury Vapour at Human-Relevant Concentration. Toxicol Sci 2004, 80:69-73.

53. Luglie PF, Campus G, Chessa G, Spano G, Capobianco G, Fadda GM, Dessole $S$ : Effect of amalgam fillings on the mercury concentration in human amniotic fluid. Arch Gynecol Obstet 2005, 271:138-142.

54. Drasch G, Aigner S, Roider G, Staiger F, Lipowskyn G: Mercury in human colostrum and early breast milk. Its dependence on dental amalgam and other factors. J Trace Elem Med Biol 1998, 12:23-27.

55. Oskarsson A, Schultz A, Skerfving S, Hallen IP, Ohlin B, Lagerkvist BJ: Total and inorganic mercury in breast milk in relation to fish consumption and amalgam in lactating women. Arch Environ Health 1996, 51:234-241.

56. Vimy MJ, Hooper DE, King WW, Lorscheider FL: Mercury from maternal "silver" tooth fillings in sheep and human breast milk. A source of neonatal exposure. Biol Trace Element Res 1997, 56:143-152.

57. Waly M, Olteanu H, Banerjee R, Choi SW, Mason JB, Parker BS, Sukumar S, Shim S, Sharma A, Benzecry JM, Power-Charnitsky VA, Deth RC: Activation of methionine synthase by insulin-like growth factor and dopamine: a target for neurodevelopmental toxins and thimerosal. Mol Psychiatry 2004, 9:358-370.

58. Deth RC: Truth revealed: New scientific discoveries regarding mercury in medicine and autism. Congression Testimony before the US House of Representatives. Subcommittee in human rights and wellness 2004.

59. Palkovicova L, Ursinyova M, Masanova V, Yu Z, Hertz-Picciotto I: Maternal amalgam dental fillings as the source of mercury exposure in developing fetus and newborn. J Expo Sci Environ Epidemiol 2008, 18(Suppl 3):326-331.

60. Unuvar $\mathrm{E}$, Ahmadov H, Kiziler AR: Mercury levels in cord blood and meconium of healthy newborns and venous blood of their mothers: Clinical, prospective cohort study. Sci Total Environ 2007, 374(Suppl 1):60-70.

61. Jedrychowski W, Jankowski J, Flak E, Skarupa A, Mroz E, Sochacka-Tatara E, Lisowska-Miszczyk I, Szpanowska-Wohn A, Rauh V, Skolicki Z, Kaim I, Perera F: Effects of prenatal exposure to mercury on cognitive and psychomotor function in one-year-old infants: epidemiologic cohort study in Poland. Ann Epidemiol 2006, 16:439-447.

62. Stoz F, Aicham P, Jovanovic S, Steuer W, Mayer R: Ist ein generelles Amalgam-Verbot gerechtfertigt? [Is a generalized amalgam banning appropriate?]. Z Geburtsh Neonat 1995, 199:35-41.

63. Hargreaves RJ, Evans JG, Janota I, Magos L, Cavanagh JB: Persistant mercury in nerve cells 16 years after metallic mercury poisoning. Neuropath Appl Neurobiol 1988, 14:443-452.

64. Opitz H, Schweinsberg F, Grossmann T, Wendt-Gallitelli MF, Meyermann R: Demonstration of mercury in the human brain and other organs 17 years after metallic mercury exposure. Clin Neuropath 1996, 15:139-144.

65. Drasch G, Böse-O'Reilly S, Beinhoff C, Roider G, Maydl S: The Mt. Diwata study on the Philippines 1999 - assessing mercury intoxication of the population by small scale gold mining. Sci Total Environ 2001, 267:151-168

66. Drasch G, Böse-O'Reilly S, Maydl S, Roider G: Scientific comment on the German human biological monitoring values (HBM values) for mercury. Int J Hyg Environ Health 2002, 205:509-512.

67. Drasch G, Böse-O'Reilly S, Maydl S, Roider G: Response to the letter of the Human Biomonitoring Commission. Int J Hyg Environ Health 2004, 207:183-184.

68. Stenman S, Grans L: Symptoms and differential diagnosis of patients fearing mercury toxicity from amalgam fillings. Scand J Work Environ Health 1997, 23:59-63.

69. Grandjean P, Weihe P, White R: Milestone development in infants exposed to methylmercury from human milk. Neurotoxicology 1995, 16:27-33.

70. Köhler W, Linde K, Halbach S, Zilker T, Kremers L, Saller R, Melchart D: Prognos in the diagnosos of amalgam hypersensitivity: a diagnostic case-control study. Forsch Komplement Med 2007, 14:18-24. 
71. WHO: Mercury in Health Care. Policy Paper 2005 [http://www.who.int/ water_sanitation_health/medicalwaste/mercurypolpaper.pdf].

72. Viola P, Cassano GB: The effect of chlorine on mercury vapor intoxication. Autoradiographic study. Med Lavoro 1968, 59:437-44.

73. Kishi R, Doi R, Fukuchi Y, Satoh H, Satoh T, Ono A, Moriwaka F, Tashiro K, Takahata N: Subjective symptoms and neurobehavioral performances of ex-mercury miners at an average of 18 years after the cessation of chronic exposure to mercury vapor. Mercury Workers Study Group. Environl Res 1993, 62:289-302.

74. Mathiesen T, Ellingsen DG, Kjuus H: Neuropsychological effects associated with exposure to mercury vapor among former chloralkali workers. Scand J Work Environ Health 1999, 25:342-350.

75. Meyer-Baron M, Schaeper M, Seeber A: A meta-analysis for neurobehavioral results due to occupational mercury exposure. Arch Toxicol 2002, 76:127-136.

76. Piikivi L, Hanninen H, Martelin T, Mantere P: Psychological performance and long-term exposure to mercury vapors. Scand J Work Environ Health 1984, 10:35-41.

77. Roels H, Gennart JP, Lauwerys R, Buchet JP, Malchaire J, Bernard A: Surveillance of workers exposed to mercury vapour: validation of a previously proposed biological threshold limit value for mercury concentration in urine. Am J Ind Med 1985, 7:45-71.

78. Smith PJ, Langolf GD, Goldberg J: Effects of occupational exposure to elemental mercury on short term memory. Br J Ind Med 1983, 40:413-419.

79. Soleo L, Urbano ML, Petrera V, Ambrosi L: Effects of low exposure to inorganic mercury on psychological performance. Brit J Ind Med 1990, 47:105-109.

80. Williamson AM, Teo RK, Sanderson J: Occupational mercury exposure and its consequences for behaviour. Int Arch Occup Environ Health. 1982, 50:273-286.

81. Zavariz C, Glina DM: Clinico-neuro-psychological evaluation of workers exposed to metallic mercury in the electric lamp industry. Rev Saud Publica 1992, 26:356-65, (In Portugese with English abstract).

82. He F, Zhow $X$, Lin B, Xiung YP, Chen SY, Zhang SL, Ru JY, Deng MH: Prognosis of Mercury poisoning in mercury refinery workers. Ann Acad Med Singapore 1984, 13:389-393.

83. Kishi R, Doi R, Fukushi Y, Satoh H, Ono A: Residual neurobehavioural effects associated with chronic exposure to mercury vapour. Occup Environ Med 1994, 51:35-41

84. Kobal A, Horvat M, Prezelj M, Briski AS, Krsnik M, Dizdarevic T, Mazej D, Falnoga I, Stibilj V, Arneric N, Kobal D, Osredkar J: The impact of longterm past exposure to elemental mercury on antioxidative capacity and lipid peroxidation in mercury miners. I Trace Elem Med Biol 2004, 17:261-274.

85. Letz R, Gerr F, Cragle D, Green R, Watkins J, Fidler A: Residual neurologic deficits 30 years after occupational exposure to elemental mercury. Neurotoxicology 2000, 21:459-474.

86. Sugita M: The biological half-time of heavy metals. The existence of a third, 'slowest' component. Int Arch Occup Environ Health 1978, 41:25-40.

87. Takahata N, Hayashi H, Watanabe S, Anso T: Accumulation of mercury in the brains of two autopsy cases with chronic inorganic mercury poisoning. Folia Psychiatr Neurol Jpn 1970, 24:59-69.

88. Stoiber T, Bonacker D, Bohm K: Disturbed microtubule function and induction of micronuclei by chelate complexes of mercury(II). Mutat Res 2004, 563:97-106.

89. Stoiber T, Degen GH, Bolt HM, Unger E: Interaction of mercury(II) with the microtubule cytoskeleton in IMR-32 neuroblastoma cells. Toxicol Lett 2004, 151(Suppl 1):99-104.

90. Thier R, Bonacker D, Stoiber T: Interaction of metal salts with cytoskeletal motor protein systems. Toxicol Lett 2003, 140:75-81.

91. Duhr EF, Pendergrass JC, Slevin JT, Haley BE: HgEDTA complex inhibits GTP interactions with the E-site of brain beta-tubulin. Toxicol Appl Pharmacol 1993, 122:273-280

92. Pendergrass JC, Haley BE, Vimy MJ, Winfield SA, Lorscheider FL: Mercury vapor inhalation inhibits binding of GTP to tubulin in rat brain: similarity to a molecular lesion in Alzheimer diseased brain. Neurotoxicology 1996, 18:315-324.

93. Soares FA, Farina M, Santos FW, Souza D, Rocha JB, Nogueira CW: Interaction between metals and chelating agents affects glutamate binding on brain synaptic membranes. Neurochem Res 2003, 28:1859-1865.
94. Aposhian HV, Morgan DL, Queen HL, Maiorino RM, Aposhian MM: Vitamin C, glutathione, or lipoic acid did not decrease brain or kidney mercury in rats exposed to mercury vapor. J Toxicol Clin Toxicol 2003, 41:339-347.

95. Nogueira CW, Soares FA, Nascimento PC, Muller D, Rocha JB: 2,3Dimercaptopropane-1-sulfonic acid and meso-2,3-dimercaptosuccinic acid increase mercury- and cadmium-induced inhibition of deltaaminolevulinate dehydratase. Toxicology 2003, 184:85-95.

96. Ewan KB, Pamphlett R: Increased inorganic mercury in spinal motor neurons follwoing chelating agents. Neurotoxicology 1996, 17:343-349.

97. Harris HH, Pickering IJ, George GN: The chemical form of mercury in fish. Science 2003, 301:1203.

98. Fredriksson A, Dencker L, Archer T, Danielsson BR: Prenatal coexposure to metallic mercury vapour and methylmercury produce interactive behavioural changes in adult rats. Neurotoxicol Teratol 1996, 18:129-134.

99. Lettmeier B, Böse O, Reilly S, Drasch G: Proposal for a revised reference concentration (RFC) for mercury vapour in adults. Sci Total Environ 2010

100. Richardson GM, Environment Division of SNC-Lavalin Inc (SLE), Ottawa (Canada):: Mercury exposure and risks from dental amalgam, part 1: updating exposure, reexamining reference exposure levels, and critically evaluating recent studies. 2010 [http://iaomt.org/articles/files/files329/ Amalgam\%20Risk\%20Assessment\%20Part\%201.SLE\%20reference\%2010738. Final2.pdf].

101. Schubert J, Riley EJ, Tyler SA: Combined effects in toxicology - a rapid systematic testing procedure: cadmium, mercury, and lead. J Toxicol Environ Health 1978, 4:763-776.

102. Haley B: The relationship of toxic effects of mercury to exacerbation of the medical condition classified as alzheimer's disease.[http://www.fda. gov/ohrms/dockets/dailys/02/Sep02/091602/80027dd5.pdf].

103. Ericson JE, Shirahata H, Patterson CC: Skeletal concentrations of lead in ancient Peruvians. N Engl J Med 1979, 300:946-951.

104. Ericson JE, Smith DR, Flegal AR: Skeletal concentrations of lead, cadmium, zinc, and silver in ancient North American Pecos Indians. Environ Health Perspect 1991, 93:217-223.

105. Drasch G: Lead burden in prehistorical, historical and modern human bones. Sci Total Environ 1982, 24:199-231.

106. Patterson CC, Shirahata H, Ericson JE: Lead in ancient human bones and the relevance to historical developments of social problems with lead. Sci Total Environ 1987, 61:167-200.

107. Patterson CC, Shirahata H, Ericson JE: Natural skeletal levels of lead in Homo sapiens sapiens uncontaminated by technological lead. Sci Total Environ 1991, 107:205-236.

108. Haley B: Mercury toxicity: Genetic susceptibilities and synergistic effects. Medical Veritas 2005, 2:535-542.

109. Haley B, Small T: Biomarkers supporting mercury toxicity as the major exacerbator of neurological illness, recent evidence via the urine prophyrin tests. Medical Veritas 2006, 3:1-14.

110. Kehe K, Reichl FX, Durner J, Walther U, Hickel R, Forth W: Cytotoxicity of dental composite components and mercury compounds in pulmonary cells. Biomaterials 2001, 22:317-322.

111. Reichl FX, Walther UI, Durner J, Kehe K, Hickel R, Kunzelmann KH, Spahl W, Hume WR, Benschop H, Forth W: Cytotoxicity of dental composite components and mercury compounds in lung cells. Dent Mater 2001, 17:95-101.

112. Reichl FX, Simon S, Esters M, Seiss M, Kehe K, Kleinsasser N, Hickel R: Cytotoxicity of dental composite (co)monomers and the amalgam component $\mathrm{Hg}(2+)$ in human gingival fibroblasts. Arch Toxicol 2006, 80:465-472.

113. Reichl FX, Esters M, Simon S, Seiss M, Kehe K, Kleinsasser N, Folwaczny M, Glas J, Hickel R: Cell death effects of resin-based dental material compounds and mercurials in human gingival fibroblast. Arch Toxicol 2006, 80:370-377.

114. Walther UI, Walther SC, Liebl B, Kehe K, Hickel R, Kunzelmann KH, Spahl W, Hume WR, Benschop H, Forth W: Cytotoxicity of ingredients of various dental materials and related compounds in L2- and A549 cells. J Biomed Mater Res 2002, 63:643-649.

115. Di Pietro A, Visalli G, La Maestra S: Biomonitoring of DNA damage in peripheral blood lymphocytes of subjects with dental restorative fillings. Mutat Res 2008, 650:115-122.

116. Schmid K, Sassen A, Staudenmaier R: Mercury dichloride induces DNAdamage in human salivary gland tissue calls and lymphocytes. Arch Toxicol 2007, 1:759-767. 
117. Akiyama M, Oshima H, Nakamura M: Genotoxicity of mercury used in chromosome aberration tests. Toxicol in Vitro 2001, 15:463-467.

118. Pizzichini M, Fonzi M, Sugherini L, Fonzi L, Gasparoni A, Comporti M, Pompella A: Release of mercury from dental amalgam and its influence on salivary antioxidant activity. Bull Group Int Rech Sci Stomatol Odontol 2000, 42:94-100

119. Pizzichini M, Fonzi M, Sugherini L, Fonzi L, Comporti M, Gasparoni A, Pompella A: Release of mercury from dental amalgam and its influence on salivary antioxidant activity. Sci Total Environ 2002, 284:19-25.

120. Pizzichini M, Fonzi M, Gasparoni A, Fonzi L, Comporti M, Gasparoni A, Pompella $\mathrm{A}$ : Influence of amalgam fillings on $\mathrm{Hg}$ levels and total antioxidant activity in plasma of healthy donors. Bull Group Int Rech Sci Stomatol Odontol 2001, 43:62-67.

121. Pizzichini M, Fonzi M, Giannerini F, Mencarelli M, Gasparoni A, Rocchi G, Kaitsas $\mathrm{V}$, Fonzi L: Influence of amalgam fillings on $\mathrm{Hg}$ levels and total antioxidant activity in plasma of healthy donors. Sci Total Environ 2003, 301:43-50

122. Ionescu JG, Novotny J, Stejskal V, Lätsch A, Blaurock-Busch E, EisenmannKlein M: Increased levels of transition metals in breast cancer tissue. Neuro Endocrinol Lett 2006, 27:36-39.

123. Drasch G, Mailänder S, Schlosser C, Roider G: Content of non-mercuryassociated selenium in human tissues. Biol Trace Element Res 2000, 77:219-230.

124. Mutter J, Curth A, Naumann J, Deth R, Walach H: Does Inorganic Mercury Play a Role in Alzheimer's Disease? A Systematic Review and an Integrated Molecular Mechanism. J Alzheimers Dis 2010, 22:357-374.

125. Liebert CA, Wireman J, Smith T, Summers AO: The impact of mercury released from dental "silver" fillings on antibiotic resistances in the primate oral and intestinal bacterial flora. Met lons Biol Syst 1997, 34:441-460.

126. Lorscheider FL, Vimy MJ, Summers AO, Zwiers $\mathrm{H}$ : The dental amalgam mercury controversy-inorganic mercury and the CNS; genetic linkage of mercury and antibiotic resistances in intestinal bacteria. Toxicology 1995 97:19-22.

127. Summers AO, Wireman J, Vimy MJ, Lorscheider FL, Marshall B, Levy SB: Mercury released from dental "silver" fillings provokes an increase in mercury- and antibiotic-resistant bacteria in oral and intestinal floras of primates. Antimicrob Agents Chemother 1993, 37:825-834.

128. Davis IJ, Roberts AP, Ready D, Richards H, Wilson M, Mullany P: Linkage of a novel mercury resistance operon with streptomycin resistance on a conjugative plasmid in Enterococcus faecium. Plasmid 2005, 54:26-38.

129. Skurnik D, Ruimy R, Ready D, Ruppe E, Bernède-Bauduin C, Djossou F, Guillemot D, Pier GB, Andremont A: Is exposure to mercury a driving force for the carriage of antibiotic resistance genes? J Med Microbiol 2010, 59:804-807.

130. Leistevuo J, Jarvinen H, Osterblad M, Leistevuo T, Huovinen P, Tenovuo J: Resistance to mercury and antimicrobial agents in Streptococcus mutans isolates from human subjects in relation to exposure to dental amalgam fillings. Antimicrob Agents Chemother 2000, 44:456-457.

131. Pike R, Lucas V, Stapleton P, Gilthorpe MS, Roberts G, Rowbury R, Richards $H$, Mullany $P$, Wilson M: Prevalence and antibiotic resistance profile of mercury-resistant oral bacteria from children with and without mercury amalgam fillings. J Antimicrob Chemother 2002, 49:777-783.

132. Wireman J, Liebert CA, Smith T, Summers AO: Association of mercury resistance with antibiotic resistance in the gram-negative fecal bacteria of primates. Appl Environ Microbiol 1997, 63:4494-4503.

133. Harris HH, Vogt $S$, Eastgate $H$, Legnini DG, Hornberger B, Cai Z, Lai B, Lay PA: Migration of mercury from dental amalgam through human teeth. J Synchrotron Radiat 2008, 15:123-128.

134. Weidinger S, Kramer U, Dunemann L, Mohrenschlager M, Ring J, Behrendt $\mathrm{H}$ : Body burden of mercury is associated with acute atopic eczema and total IgE in children from southern Germany. J Allergy Clin Immunol 2004, 114:457-459.

135. Berlin M: Mercury in dental-filling materials - an updated risk analysis in environmental medical terms. The Dental Material Comission - Care and Consideration Sweden; 2003.

136. Dunsche A, Frank M, Luttges J, Açil Y, Brasch J, Christophers E, Springer IN: Lichenoid reactions of murine mucosa associated with amalgam. $\mathrm{Br} J$ Dermatol 2003, 148:741-748.
137. Dunsche A, Kastel I, Terheyden H, Springer I, Christophers E, Brasch J: Oral lichenoid reactions associated with amalgam: improvement after amalgam removal. Br J Dermatol 2003, 148:70-76.

138. Martin M, Broughton S, Drangsholt M: Oral lichen planus and dental materials: a case-control study. Contact Dermatitis 2003, 48:331-336.

139. Wong L, Freeman S: Oral lichenid lesions (OLL) and mercury in amalgam fillings. Contact Dermatitis 2003, 48:74-79.

140. Guttman-Yassky E, Weltfriend S, Bergman R: Resolution of orofacial granulomatosis with amalgam removal. J Eur Acad Dermatol Venerol 2003, 17:344-347.

141. Guarneri F, Marini H: Perioral dermatitis after dental filling in a 12-yearold girl: involvement of cholinergic system in skin neuroinflammation? ScientificWorldJournal 2008, 8:157-163.

142. Pigatto PD, Brambilla L, Guzzi G: Mercury pink exanthem after dental amalgam placement. J Eur Acad Dermatol Venereol 2008, 22:377-378.

143. Bartova J, Prochazkova J, Kratka Z, Benetkova K, Venclikova Z, Sterzl I: Dental amalgam as one of the risk factors in autoimmune diseases. Neuro Endocrinol Lett 2003, 24:65-67.

144. Hultman P, Johansson U, Turley S, Lindh U, Enestrom S, Pollard K: Adverse immunological effects and autoimmunity induced by dental amalgam and alloy in mice. FASEB Journal 1994, 8:1183-1190.

145. Hultman P, Lindh $U$, Horsted-Binslev P: Activation of the immune system and systemic immune-complex deposits in Brown Norway rats with dental amalgam restorations. J Dent Res 1998, 77:1415-1425.

146. Pollard KM, Pearson DL, Hultman P, Deane TN, Lindh U, Kono DH: Xenobiotic acceleration of idiopathic systemic autoimmunity in lupusprone bxbs mice. Environ Health Persp 2001, 109:27-33.

147. Prochazkova J, Sterzl I, Kucerova H, Bartova J, Stejskal VDM: The beneficial effect of amalgam replacement on health in patients with autoimmunity. Neuro Endocrinol Lett 2004, 25:211-218.

148. Stejskal J, Stejskal VD: The role of metals in autoimmunity and the link to neuroendocrinology. Neuro Endocrinol Lett 1999, 20:351-364.

149. Stejskal VD, Danersund A, Lindvall A: Metal-specific lymphocytes: biomarkers of sensitivity in man. Neuro Endocrinol Lett 1999, 20:289-298.

150. Sterzl I, Procházková J, Hrdá P, Bártová J, Matucha P, Stejskal VDM: Mercury and nickel allergy: risk factors in fatigue and autoimmunity. Neuro Endocrinol Lett 1999, 20:221-228.

151. Via CS, Nguyen P, Niculescu F, Papadimitriou J, Hoover D, Silbergeld EK: Low-dose exposure to inorganic mercury accelerates disease and mortality in acquired murine lupus. Environ Health Perspect 2003, 111:1273-1277.

152. Sterzl I, Procházková J, Hrda P, Matucha P, Bartova J, Stejskal V: Removal of dental amalgam decreases anto-TPO and anti-Tg autoantibodies in patients with autoimmune thyroiditis. Neuro Endocrinol Lett 2006, 5(27 (Suppl 1):25-30

153. Kazantzis G: Mercury exposure and early effects: an overview. Med Lav 2002, 93:139-147.

154. Rampersad GC, Suck G, Sakac D, Fahim S, Foo A, Denomme GA, Langler RF, Branch DR: Chemical compounds that target thiol-disulfide groups on mononuclear phagocytes inhibit immune mediated phagocytosis of red blood cells. Transfusion 2005, 45:384-393.

155. Bartram F, Donate HP, Müller KE, Bückendorf $\mathrm{CH}$, Ohnsorge $\mathrm{P}$, Huber W, von Baehr $V$ : Significance of the patch test and the lymphocyte transformation test in the diagnostic of type IV-sensitazion. J Lab Med 2006, 30:101-106.

156. Venclíková Z, Benada O, Bártová J, Joska L, Mrklas L, Procházková J, Stejskal V, Podzimek S: In vivo effects of dental casting alloys. Neuro Endocrinol Lett 2006, 27(Suppl 1):61-68.

157. Valentine-Thon E, Schiwara HW: Validity of MELISA for metal sensitivity testing. Neuro Endocrinol Lett 2003, 24:50-55

158. Valentine-Thon E, Sandkamo M, Müller K, Guzzi G, Hartmann T: Metallsensibilisierung: Nachweis, Validierung und Verlaufskontrolle mittels Lymphozyten-Transformations-Test (LTT-Melisa $\left.{ }^{\circledR}\right)$. Zs $f$ Orthomol Med 2005, 1:12-15

159. Valentine-Thon E, Muller KE, Guzzi G, Kreisel S, Ohnsorge P, Sandkamp M: LTT-MELISA ${ }^{\circledast}$ is clinically relevant for detecting and monitoring metal sensitivity. Neuro Endocrinol Lett 2006, 27(Suppl1):17-24.

160. Yaqob A, Danersund A, Stejskal VD, Lindvall A, Hudecek R, Lindh U: Metalspecific lymphocyte reactivity is downregulated after dental metal replacement. Neuro Endocrinol Lett 2006, 27:189-197. 
161. Lindh U, Hudecek R, Dandersund A, Eriksson S, Lindvall A: Removal of dental amalgam and other metal alloys supported by antioxidant therapy alleviates symptoms and improves quality of life in patients with amalgam-associated ill health. Neuro Endocrinol Lett 2002, 23:459-482.

162. Stejskal VD: Diagnosis and treatment of metal-induced side effects. Neuro Endocrinol Lett 2006, 27(Suppl 1):7-16.

163. Wortberg W: Intrauterine Fruchtschädigung durch Schwermetallbelastung der Mutter. Umwelt Medizin Gesellschaft 2006, 19:274-280.

164. Houston MC: The role of mercury and cadmium heavy metals in vascular disease, hypertension, coronary heart disease, and myocardial infarction. Altern Ther Health Med 2007, 13:128-133,

165. Frustaci A, Magnavita N, Chimenti C, Cladarulo M, Sabbioni E, Pietra R: Marked elevation of myocardial trace elements in idiopathic dilated cardiomyopathy compared with secondary cardiac dysfunction. J Am Coll Cardiol 1999, 33:1578-1583.

166. Dodes JE: The amalgam controversy. An evidence-based analysis. J Am Dent Assoc 2001, 132:348-356.

167. Boyd ND, Benediktsson H, Vimy MJ, Hooper DE, Lorscheider FL: Mercury from dental "silver" tooth fillings impairs sheep kidney function. Am J Physiol 1991, 261:1010-1014.

168. Trachtenberg F, Barregård L: The effect of age, sex, and race on urinary markers of kidney damage in children. Am J Kidney Dis 2007, 50:938-945

169. Mutter J, Naumann J, Sadaghiani C, Walach H: Quecksilber und die Alzheimer-Erkrankung. Fortschr Neuro Psychiat 2007, 75:528-538.

170. Mutter J, Naumann J, Guethlin C: Comments on the article "the toxicology of mercury and its chemical compounds" by Clarkson and Magos (2006). Crit Rev Toxicol 2007, 37:537-549.

171. Carpenter DO: Effects of metals on the nervous system of humans and animals. Int J Occup Med Environ Health 2001, 14:209-218.

172. Dantzig PI: Parkinson's disease, macular degeneration and cutaneous signs of mercury toxicity. J Occup Environ Med 2006, 48:656.

173. Finkelstein $Y$, Vardi J, Kesten MM, Hod I: The enigma of parkinsonism in chronic borderline mercury intoxication, resolved by challenge with penicillamine. Neurotoxicology 1996, 17:291-295.

174. Gorell JM, Rybicki BA, Johnson C, Peterson EL: Occupational metal exposures and the risk of Parkinson's disease. Neuroepidemiology 1999, 18:303-308.

175. Miller K, Ochudto S, Opala G, Smolicha W, Siuda J: Parkinsonism in chronic occupational metallic mercury intoxication. Neurol Neurochir Pol 2003, 37:31-38.

176. Ngim CH, Devathasan G: Epidemiologic study on the association between body burden mercury level and idiopathic Parkinson's disease. Neuroepidemiology 1989, 8:128-141.

177. Ohlson CG, Hogstedt C: Parkinson's disease and occupational exposure to organic solvents, agricultural chemicals and mercury - a case-referent study. Scand J Work Environ Health 1981, 7:252-256.

178. Rybicki BA, Johnson CC, Uman J, Gorell JM: Parkinson's disease mortality and the industrial use of heavy metals in Michigan. Mov Disord 1993, 8:87-92.

179. Seidler A, Hellenbrand W, Robra BP: Possible environmental, occupational, and other etiologic factors for Parkinson's disease: a case-control study in Germany. Neurology 1996, 46:1275-84.

180. Uversky VN, Li J, Fink AL: Metal-triggered structural transformations, aggregation, and fibrillation of human alpha-synuclein. A possible molecular NK between Parkinson's disease and heavy metal exposure. J Biol Chem 2001, 276:44284-44296.

181. Harakeh S, Sabra N, Kassak K, Doughan B, Sukhn C: Mercury and arsenic levels among Lebanese dentists: a call for action. Bull Environ Contam Toxicol 2003, 70:629-635.

182. Tezel H, Ertas OS, Ozata F, Erakin C, Kayali A: Blood mercury levels of dental students and dentists at a dental school. Br Dent J 2001, 191:449-452

183. Aydin N, Karaoglanoglu S, Yigit A, Keles MS, Kirpinar I, Seven N: Neuropsychological effects of low mercury exposure in dental staff in Erzurum, Turkey. Int Dent J 2003, 53:85-91.

184. Bittner ACJ, Echeverria D, Woods JS: Behavioral effects of low-level exposure to $\mathrm{HgO}$ among dental professional: a cross-study evaluation of psychomotor effects. Neuortoxicol Teratol 1998, 17:161-168.

185. Echeverria D, Heyer NJ, Martin MD, Naleway C, Woods JS, Bittner ACJ: Behavioral effects of low-level exposure to elemental $\mathrm{Hg}$ among dentists. Neurotoxicol Teratol 1995, 17:161-168.
186. Echeverria D, Woods JS, Heyer N, Rohlman DS, Farin FM, Bittner AC Jr, Li T, Garabedian C: Chronic low-level mercury exposure, BDNF polymorphism and associations with cognitive and motor function. Neurotoxicol Teratol 2005, 27:781-796.

187. Heyer NJ, Echeverria D, Bittner AJ, Farin FM, Garabedian CC, Woods JS: Chronic low-level mercury exposure, BDNF polymorphism, and associations with self-reported symptoms and mood. Toxicol Sci 2004 81:354-363.

188. Heyer NJ, Bittner AJ, Echerverria D, Woods J: A cascade analysis of the interaction of mercury and coproporphyrinogen-oxidase (CPOX) polymorphism on the heme biosynthetic pathway and porphyrin production. Toxicol Lett 2006, 161:159-166.

189. Gonzalez-Ramirez D, Maiorino RM, Zuniga-Charles M: Sodium 2,3dimercaptopropane-1-sulfonate challenge test for mercury in humans: II. Urinary mercury, porphyrins and neurobehavioral changes of dental workers in Monterrey, Mexico. J Pharmacol Exp Ther 1995, 272:264-274.

190. Langworth S, Sallsten G, Barregard L, Cynkier I, Lind ML, Soderman E: Exposure to mercury vapor and impact on health in the dental profession in Sweden. J Dent Res 1997, 76:1397-1404.

191. Moen BE, Hollund BE, Riise T: Neurological symptoms among dental assistants: a cross-sectional study. J Occup Med Toxicol 2008, 18:3-10

192. Ngim CH, Foo SC, Boey KW, Jeyaratnam J: Chronic neurobehavioral effects of elemental mercury in dentists. $\mathrm{Br} J$ Ind Med 1992, M49:782-790.

193. Ritchie KA, Macdonald EB, Hammersley R, O'Neil JM, McGowan DA, Dale IM, Wesnes K: A pilot study of the effect of low level exposure to mercury on the health of dental surgeons. J Occup Environ Med 1995, 52:813-817.

194. Ritchie KA, Gilmour WH, Macdonald EB, Burke FJ, McGowan DA, Dale IM, Hammersley R, Hamilton RM, Binnie V, Collington D: Health and neuropsychological functioning of dentists exposed to mercury. J Occup Environ Med 2002, 59:287-293.

195. Uzzell BP, Oler J: Chronic low-level mercury exposure and neuropsychological functioning. J Clin Exp Neuropsychol 1986, 8:581-593.

196. Urban P, Lukas E, Nerudova J, Cabelkova Z, Cikrt M: Neurological and electrophysiological examinations on three groups of workers with different levels of exposure to mercury vapors. Eur J Neurol 1999, 6:571-577.

197. Nadorfy-Lopez E, Torres SH, Finol H, Mendez M, Bello B: Skeletal muscle abnormalities associated with occupational exposure to mercury vapors. Hist Histopath 2000, 15:673-682

198. Rowland A, Baird D, Weinberg C, Shore D, Shy C, Wilcox A: The effect of occupational exposure to the mercury vapour on the fertility of female dental assistants. Occup Environ Med 1994, 51:28-34

199. Lindbohm ML, Ylöstalo P, Sallmen M: Occupational exposure in dentistry and miscarriage. Occup Environ Med 2007, 64:127-133.

200. Jones $L$, Bunnell J, Stillman J: A 30-year follow-up of residual effects on New Zealand School Dental Nurses, from occupational mercury exposure. Hum Exp Toxicol 2007, 26:367-374.

201. Echeverria D, Woods JS, Heyer NJ, Rohlman D, Farin FM, Li T, Garabedian CE: The association between a genetic polymorphism of coproporphyrinogen oxidase, dental mercury exposure and neurobehavioral response in humans. Neurotoxicol Teratol 2006, 28:39-48.

202. Gerhard I, Monga B, Waldbrenner A, Runnebaum B: Heavy metals and fertility. J Toxicol Environ Health. 1998, 54:593-611.

203. Gerhard I, Waibel S, Daniel V, Runnebaum B: Impact of heavy metals on hormonal and immunological factors in women with repeated miscarriages. Hum Reprod Update 1998, 4:301-309.

204. Gerhard I, Runnebaum B: The limits of hormone substitution in pollutant exposure and fertility disorders. Zentralb/ Gynaekol 1992, 114:593-602.

205. Sheiner EK, Sheiner E, Hammel RD, Potashnik G, Carel R: Effect of occupational exposures on male fertility: literature review. Ind Health 2003, 41:5:5-62.

206. Podzimek S, Prochazkova J, Pribylova L, Bártová J, Ulcová-Gallová Z, Mrklas L, Stejskal VD: Effect of heavy metals on immune reactions in patients with infertility. Cas Lek Cesk 2003, 142:285-288.

207. Podzimek S, Prochazkova J, Bultasova L, Bartova J, Ulcova-Gallova Z, Mrklas L, Stejskal VD: Sensitization to inorganic mercury could be a risk factor for infertility. Neuro Endocrinol Lett 2005, 26:277-282.

208. Ahlrot-Westerlund B: Mercury in cerebrospinal fluid in multiple sclerosis Swed J Biol Med 1989, 1:6-7.

209. Craelius W: Comperative epidemiology of multiple sclerosis and dental caries. J Epidemiol Comm Health 1978, 32:155-165. 
210. McGrother C, Dugmore C, Phillips M, Raymond N, Garrick P, Baird W: Multiple sclerosis, dental caries and fillings: a case-control study. $\mathrm{Br}$ Dent J 1999, 187:261-264.

211. Baasch E: Theoretical considerations on the etiology of multiple sclerosis. Is multiple sclerosis a mercury allergy? Schweiz Arch Neurol Neurochir Psychiatr 1966, 98:1-19.

212. Ingalls T: Epidemiology, etiology and prevention of multiple sclerosis. Hypothesis and fact. Am J Forensic Med Pathol 1983, 4:55-61.

213. Ingalls T: Endemic clustering of multiple sclerosis in time and place, 1934-1984. Confirmation of a hypothesis. Am J Forensic Med Pathol 1986, 7:3-8

214. Issa Y, Watts D, Duxbury A, Brunton P, Watson M, Waters C: Mercuric chloride: toxicity and apoptosis in a human oligodendroglial cell line. Biomaterials 2003, 24:981-987.

215. Siblerud RL: A comparison of mental health of multiple sclerosis patients with silver/mercury dental fillings and those with fillings removed. Psychol Rep 1992, 70:1139-1151.

216. Siblerud RL, Kienholz E, Motl J: Evidence that mercury from silver dental fillings may be an etiological factor in smoking. Toxicol Lett 1993, 68:307-310.

217. Huggins HA, Levy TE: Cerebrospinal fluid protein changes in multiple sclerosis after dental amalgam removal. Altern Med Rev 1998, 4:295-300.

218. Bates M, Fawcett J, Garrett N, Cutress T, Kjellstrom T: Related articles, health effects of dental amalgam exposure: a retrospective cohort study. Int J Epidemiol 2004, 33:894-902.

219. Bates MN: Mercury amalgam dental fillings: an epidemiologic assessment. Int J Hyg Environ Health 2006, 209(Suppl 4):309-316.

220. Aminzadeh KK, Etminan M: Dental amalgam and multiple sclerosis: a systematic review and meta-analysis. J Public Health Dent 2007, 67:64-66.

221. Pamphlett R, Coote P: Entry of low doses of mercury vapor into the nervous system. Neurotoxicology 1998, 19:39-47.

222. Pamphlett $R$, Slater $M$, Thomas S: Oxidative damage to nuclic acids in motor neurons containing mercury. J Neurol Sci 1998, 159:121-126.

223. Pamphlett R, Waley P: Motor neuron uptake of low dose inorganic mercury. J Neurol Sci 1996, 135:63-67.

224. Praline J, Guennoc AM, Limousin N, Hallak H, deToffol B, Corcia P: ALS and mercury intoxication: a relationship? Clin Neurol Neurosurg 2007, 109(Suppl 10):880-883

225. Stankovic R: Atrophy of large myelinated motor axons and declining muscle grip strength following mercury vapour inhalation in mice. Inhal Toxicol 2006, 18:57-69.

226. Albrecht J, Matya E: Glutamate: a potential mediator of inorganic mercury neurotoxicity. Metab Brain Dis 1996, 11:175-184

227. Adams C, Ziegler D, Lin J: Mercury intoxication simulating amyotrophic lateral sclerosis. JAMA 1983, 250:642-643.

228. Schwarz S, Husstedt I, Bertram H, Kuchelmeister K: Amyotrophic lateral sclerosis after accidental injection of mercury. J Neurol Neurosurg Psychiatry 1996, 60:698.

229. Redhe O, Pleva J: Recovery from amyotrophic lateral sclerosis and from allergy after removal of dental amalgam fillings. Int J Risk Saf Med 1994 4:229-236

230. Engel P: Beobachtungen über die Gesundheit vor und nach Amalgamentfernung. [Observations on health before and after removing dental amalgam]. Schweiz Monatsschr Zahnm 1998, 108:2-14

231. Godfrey ME, Wojcik DP, Krone CA: Apolipoprotein E genotyping as a potential biomarker for mercury neurotoxicity. J Alz Dis 2003, 5:189-195.

232. Siblerud RL: The relationship between mercury from dental amalgam and mental health. Am J Psychother 1989, 43:575-587.

233. Siblerud RL, Motl J, Kienholz E: Psychometric evidence that mercury from silver dental fillings may be an etiological factor in depression, excessive anger, and anxiety. Psychol Rep 1994, 74:67-80.

234. Wojcik DP, Godfrey ME, Haley B: Mercury toxicity presenting as chronic fatigue, memory impairment and depression: diagnosis, treatment, susceptibility, and outcomes in a New Zealand general practice setting (1994-2006). Neuro Endocrinol Lett 2006, 27:415-423.

235. Marcusson J: Psychological and somatic subjective as a result of dermatological patch testing with metallic mercury and phenyl mercuric acetate. Toxicol Lett 1996, 84:113-122.

236. Marcusson J, Jarstrand C: Oxidative metabolism of neutrophils in vitro and human mercury intolerance. Toxicol in Vitro 1998, 12:383-388.
237. Marcusson J: The frequency of mercury intolerance in patients with chronic fatigue syndrome and healthy controls. Contact Dermatitis 1999, 41:60-61.

238. Woods J Martin, Naleway CA, Echeverria D: Urinary porphyrin profiles as a biomarker of mercury exposure: studies on dentists with occupational exposure to mercury vapor. J Toxicol Environ Health 1993, 40:235-46.

239. Nataf R, Skorupka C, Amet L, Lam A, Springbett A, Lathe R: Porphyrinuria in childhood autistic disorder: implications for environmental toxicity. Toxicol Appl Pharmacol 2006, 214:99-108.

240. Geier DA, Geier MR: A prospective assessment of porphyrins in autistic disorders: a potential marker for heavy metal exposure. Neurotox Res 2006, 10:57-64.

241. Geier DA, Geier MR: A meta-analysis epidemiological assessment of neurodevelopmental disorders following vaccines administered from 1994 through 2000 in the United States. Neuro Endocrinol Lett 2006, 27:401-413.

242. Woods JS, Echeverria D, Heyer NJ, Simmonds PL, Wilkerson J, Farin FM: The association between genetic polymorphisms of coproporphyrinogen oxidase and an atypical porphyrinogenic response to mercury exposure in humans. Toxicol Appl Pharmacol 2005, 206:113-120.

243. Atamna H, Frey WH: A Role for heme in Alzheimer's disease: Heme binds amyolid $\beta$ and has altered metabolism. PNAS 2004, 101(Suppl 30):153-158

244. Stewart WF, Schwartz BS, Simon D, Kelsey K, Todd AC: ApoE genotype, past adult lead exposure, and neurobehavioral function. Environ Health Perspect 2002, 110:501-505.

245. Mutter J, Naumann J, Schneider R, Walach H, Haley B: Mercury an autism: Accelerating evidence? Neuro Endocrinol Lett 2005, 26:431-437.

246. Mutter J, Naumann J, Walach H, Daschner F: Amalgam: Eine Risikobewertung unter Berücksichtigung der neuen Literatur bis 2005. Gesundheitswesen 2005, 67:204-216.

247. Mutter J, Naumann J, Sadaghiani C, Walach H, Drasch G: Mercury an autism: Response to the letter of K.E.v. Muehlendahl. Int J Hyg Environ Health 2005, 208:437-438

248. Kidd R: Results of dental amalgam removal and mercury detoxification using DMPS and neural therapy. Altern Ther Health 2000, 6:49-55.

249. Lindforss H, Marqvardsen O, Olsson S, Henningson M: Effekter på hälsan efter avlägsnandet av amalgamfyllingar. Enodontologisk, medicinsk och psykosomatisk studie. Tandläkartidningen 1994, 86:205-211.

250. Lygre GB, Gjerdet NR, Bjorkman L: Patients' choice of dental treatment following examination at a specialty unit for adverse reactions to dental materials. Acta Odontol Scand 2004, 62:258-263.

251. Stomberg R, Langworth S: Mercury in dental-filling materials - an updated risk analysis in environmental medical terms. The dental Material Commission - Care and Consideration.Edited by: Berlin M. Sweden 2003, 19, (1998):

252. Faustman EM, Silbernagel SM, Fenske RA, Burbacher T, Ponce RA: Mechanisms underlying children's susceptibility to environmental toxicants. Environ Health Perspect 2000, 108:13-21.

253. Cheuk DK, Wong V: Attention-deficit hyperactivity disorder and blood mercury level: a case control study in Chinese children. Neuropediatrics 2006, 37:234-240

254. Desoto MC, Hitlan RT: Blood levels of mercury are related to diagnosis of autism: a reanalysis of an important data set. J Child Neurol 2007, 22:1308-1311.

255. Adams JB, Romdalvik J, Ramanujam VM, Legator MS: Mercury, lead, and zinc in baby teeth of children with autism versus controls. J Toxicol Environ Health 2007, 70:1046-1051.

256. Evans TA, Siedlak SL, Lu L: The autistic phenotype exhibits remarkably localized modification of brain protein by products of free radicalinduced lipid oxidation. Am J Biochem Biotechnol 2008, 4:61-72.

257. Lopez-Hurtado E, Prieto JJ: A microscopic study of language-related cortex in autism. Am J Biochem Biotechnol 2008, 4:130-145.

258. Sajdel-Sulkowska EM, Lipinski B, Windom H, Audhya T, McGinnis W: Oxidative stress in autism: elevated cerebellar 3-nitrotyrosine levels. Am J Biochem Biotechnol 2008, 4:73-84.

259. Bradstreet J, Geier D, Kartzinel J, Adams J, Geier M: A case-control study of mercury burden in children with autistic spectrum disorders. J Am Phys Surg 2003, 8:76-79

260. Geier DA, Geier MR: A case series of children with apparent mercury toxic encephalopathies manifesting with clinical symptoms of regressive autistic disorders. J Toxicol Environ Health 2007, 70:837-851. 
261. Geier DA, Geier MR: A prospective study of mercury toxicity biomarkers in autistic spectrum disorders. J Toxicol Environ Health. 2007, 70:1723-1730

262. Adams JB, Baral M, Geis E, Mitchell J, Ingram J, Hensley A, Zappia I, Newmark S, Gehn E, Rubin RA, Mitchell K, Bradstreet J, El-Dahr J: Safety and efficacy of oral DMSA therapy for children with autism spectrum disorders: part B - behavioral results. BMC Clin Pharmacol 2009, 9:17.

263. Geier DA, Kern JK, Geier MR: A prospective study of prenatal mercury exposure from maternal dental amalgams and autism severity. Acta Neurobiol Exp 2009, 69:189-197.

264. Geier DA, Mumper E, Gladfelter B, Coleman L, Geier MR: Neurodevelopmental Disorders, Maternal Rh-Negativity, and Rho(D) Immune Globulins: A Multi-Center Assessment. Neuro Endocrinol Lett 2008, 29:272-280.

265. Hornig M, Chian D, Lipkin W: Neurotoxic effects of postnatal thimerosal are mouse strain dependent. Mol Psychiatry 2004, 9:833-845.

266. Amin-Zaki L, Majeed MA, Greenwood MR, Elhassani SB, Clarkson TW Doherty RA: Methylmercury poisoning in the Iraqi suckling infant: a longitudinal study over five years. J App/ Toxicol 1981, 1:210-214.

267. Counter SA, Buchanan LH, Ortega F, Laurell G: Elevated blood mercury and neuro-otological observations in children of the Ecuadorian gold mines. J Toxicol Environ Health 2002, 65:149-163.

268. Debes F, Budtz-Jorgensen E, Weihe P, White RF, Grandjean P: Impact of prenatal methylmercury exposure on neurobehavioral function at age 14 years. Neurotoxicol Teratol 2006, 28:363-75.

269. Palmer R, Blanchard S, Stein Z, Mandell D, Miller C: Environmental mercury release, special education rates and autism disorder: an ecological study of Texas. Health\&Place 2006, 12:203-209.

270. Rury J: Links between environmental mercury special education and autism in Louisiana. PhD thesis Louisiana State University, Baton Rouge (LA); 2006.

271. Windham GC, Zhang L, Gunier R, Croen LA, Grether JK: Autism spectrum disorders in relation to distribution of hazardous air pollutants in the San Francisco Bay area. Environ Health Perspect 2006, 114:1438-1444.

272. James S, Cutler P, Melnyk S, Jernigan S, Janak L, Gaylor DW, Neubrander JA: Metabolic biomarkers of increased oxidative stress and impaired methylation capacity in children with autism. Am J Clin Nutr 2004, 80:1611-1617.

273. James SJ, Slikker W, Melnyk S, New E, Pogribna M, Jernigan S: Thimerosal neurotoxicity is associated with glutathione depletion: protection with glutathione precursors. Neurotoxicology 2005, 26:1-8

274. Autism Research Institute: Treatment options for mercury/metal toxicity in autism and related developmental disabilities. [http://autism.asu.edu/ TreatmentOptions.pdf].

275. Zahir F, Rizwi SJ, Haq SK, Khan RH: Low dose mercury toxicity and human health. Environ Toxicol Pharmacol 2005, 20:351-360.

276. Bjorkman L, Pedersen NL, Lichtenstein P: Physical and mental health related to dental amalgam fillings in Swedish twins. Community Dent Oral Epidemiol 1996, 24:260-267.

277. Bellinger DC, Needleman HL: Intellectual impairment and blood lead levels. N Eng J Med 2003, 349:500-502.

278. DeRouen TA, Martin MD, Leroux BG: Neurobehavioral effects of dental amalgam in children: a randomized clinical trial. JAMA 2006, 295(Suppl 15):1784-1792

279. Buyske S, Williams TA, Mars AE, Stenroos ES, Ming SX, Wang R, Sreenath M, Factura MF, Reddy C, Lambert GH, Johnson WG: Analysis of case-parent trios at a locus with a deletion allele: association of GSTM1 with autism. BMC Genet 2006, 7:8

280. Chew CL, Soh G, Lee AS, Yeoh TS: Long-term dissolution of mercury from a non-mercury-releasing amalgam. Clin Prev Dent 1991, 13(Suppl 3):5-7.

281. UNEP (United Nations Environment Programm Chemicals): Global Mercury Assessment 2002. [http://www.chem.unep.ch/mercury/Report/GMA-reportTOC.htm].

282. Laks DR: Assessment of chronic mercury exposure within the U.S. population, National Health and Nutrition Examination Survey, 19992006. Biometals 2009, [Epub ahead of print].

283. Hylander L, Goodsite M: Environmental costs of the mercury pollution. SC Total Environ 2006, 368:352-370.

284. Hylander L, Lindvall A, Gahnberg L: High mercury emissions from dental clinics despite amalgam separators. Sci Total Environ 2006, 362:74-84.
285. Hylander L, Lindvall A, Uhrberg R, Gahnberg L, Lindh U: Mercury recovery in situ of four different dental amalgam separators. Sci Total Environ 2006, 366:320-336.

286. Bender M: Taking a bite out of dental mercury pollution. New England zero Mercury Campaign.[http://mpp.cclearn.org/wp-content/uploads/2008/ 08/nezmc_report_card_on_dental_mercuryfinal.pdf].

287. Bengtsson U: The symbiosis between the dental and industrial communities and their scientific journals.[http://www.gbg.bonet.se/bwf/ art/symbiosis.html]

288. Consumer for Dental Choice: Complaint against FDA. 2008 [http://www. toxicteeth.org/natcamp_fedgovt_fda_complaint_Dec07.cfm].

289. FDI World Dental Federation: FDI participates at WHO/UNEP meeting on future use of materials for dental restoration. 2009 [http://www. fdiworldental.org/content/fdi-participates-whounep-meeting-future-usematerials-dental-restoration].

290. Mercury Policy Project, Bender M: Letter to WHO: WHO meeting report on the future of dental restorative materials. 2010 [http://mercurypolicy.org/ wp-content/uploads/2010/12/ letter_to_who_amalgam_nov_2010_final_final.pdf]

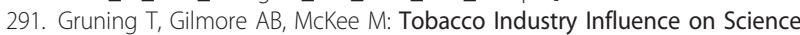
and Scientists in Germany. Am J Public Health 2006, 96:20-32.

292. Hardell L, Walker MJ, Walhjalt B, Friedman LS, Richter ED: Secret ties to industry and conflicting interests in cancer research. Am J Ind Med 2007, 50:227-233.

293. Bohm SR, Dian Z, Gilman DS: Maximizing profit and endangering health: corporate strategies to avoid litigation and regulation. Int J Occup Environ Health 2005, 11:338-348.

294. Jacobson MF: Lifting the veil of secrecy from industry funding of nonprofit health organizations. Int J Occup Environ Health 2005, 11:349-55.

295. Egilman DS, Bohme SR: Over a barrel: corporate corruption of science and its effects on workers and the environment. Int J Occup Environ Health 2005, 11:331-337.

doi:10.1186/1745-6673-6-2

Cite this article as: Mutter: Is dental amalgam safe for humans? The opinion of the scientific committee of the European Commission. Journal of Occupational Medicine and Toxicology 2011 6:2.

\section{Submit your next manuscript to BioMed Central and take full advantage of:}

- Convenient online submission

- Thorough peer review

- No space constraints or color figure charges

- Immediate publication on acceptance

- Inclusion in PubMed, CAS, Scopus and Google Scholar

- Research which is freely available for redistribution 